DEPARTMENT OF COMMERCE

BUREAU OF STANDARDS

George K. Rurgess, Director

TECHNOLOGIC PAPERS OF THE BUREAU OF STANDARDS, No. 334

[Part of Vol. 21]

\title{
RELATIONSHIPS BETWEEN THE ROCKWELL AND BRINELL NUMBERS
}

\author{
BY \\ S. N. PETRENKO, Associate Mechanical Engineer \\ Bureau of Standards
}

January 10, 1927

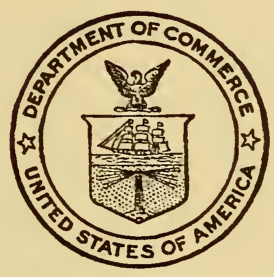

PRICE 15 CENTS

\$1.25 PER VOLUME ON SUBSCRIPTION

Sold only by the Superintendent of Documents, Government Printing Office Washington, D. C.

WASHINGTON

GOVERNMENT PRINTING OFFICE

1927 



\title{
RELATIONSHIPS BETWEEN THE ROCKWELL AND BRINELL NUMBERS
}

\author{
By S. N. Petrenko
}

ABSTRACT

Comparative Rockwell and Brinell tests were made on a great variety of ferrous and nonferrous metals.

The theoretical relationships between the Brinell and the Rockwell numbers may be expressed by the equations

$$
\text { Brinell number }=\frac{\text { constant }}{130-\text { Rockwell ball number }}
$$

and

$$
\text { Brinell number }=\frac{\text { constant }}{(100-\text { Rockwell cone number })^{2}}
$$

The experimental values of Brinell and Rockwell numbers were inserted into these equations and the constants determined. These theoretical equations with the experimentally determined constants may be used to estimate, within an error of plus or minus 10 per cent, the Brinell number from the Rockwell number. Similar equations were obtained for the tensile strengths of steels, which may, within an error of plus or minus 15 per cent, be estimated from the Rockwell number.

\section{CONTENTS}

I. Introduction . .

II. The purpose of investigation

III. Acknowledgments.

IV. Materials.

V. Apparatus_...

VI. Results of tests..._. 202

VII. Theoretical relationships_._. 203

VIII. Experimental relationships_._.

IX. Accuracy of conversion formulas..._- 210

X. Results of earlier investigators._. 217

XI. Relationships between the tensile strength and the Rockwell

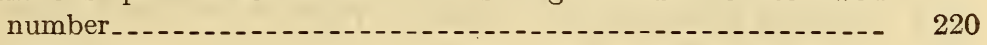

XII. Summary

\section{INTRODUCTION}

Indentation hardness tests are growing in importance as checks on the uniformity of the mechanical properties of materials for engineering structures and machines.

The indentation tests are preferred to tensile tests for this purpose because they are nondestructive and relatively cheap. A tensile test 
to destruction can obviously be applied to only relatively few samples while in many cases indentation tests can be applied to each piece produced, the indentation usually not interfering with the use of the tested piece. For materials of similar composition and manufactured by the same process uniformity of the results of indentation tests have in many cases been found to sufficiently guarantee the uniform quality of the material.

In addition, a rough parallelism has been found for steels between the Brinell number (ball indentation test) and the tensile strength.

It has been customary to define the indentation number of a material by the ratio $\frac{P}{A}$ where $P$ is the load on the indenting tool in kilograms and $A$ the surface area of the indentation in square millimeters. Previous investigators ${ }^{1}$ have shown that this ratio is not a definite constant of the material, but varies with the size and shape of the indenting tool and magnitude of the load applied. Even when, to meet the conditions of dynamic similarity, the indenting tools are geometrically similar and the loads are made proportional to the square of the linear dimensions of the tool, the ratio $\frac{P}{A}$ is, in general, different for different loads. In fact, no general relationship has been found between the load, the shape of the indenting tool, and the dimensions of the indentation. In order to secure comparable results, there has, therefore, been in the past a tendency to standardize the load and the indenting tool. Thus, in the Brinell test the Brinell number is obtained with a $10 \mathrm{~mm}$ ball and two loads, $3,000 \mathrm{~kg}$ for hard materials and $500 \mathrm{~kg}$ for soft materials. However, this size of ball and these loads can not be used satisfactorily on thin sheets or small specimens. In addition, the two operations of making the indentation and then measuring its diameter with a microscope have made the test comparatively tedious and expensive. It is evident, therefore, that a direct-reading machine for measuring indentation, applicable also to thin sheets and small specimens, has, in many practical cases, an advantage over the Brinell method.

The Rockwell machine ${ }^{2}$ uses a smaller load (usually 150 or $100 \mathrm{~kg}$ ) and a smaller indenting tool (either a cone or ball) and measures the depth of indentation.

A constant minus, the depth of indentation, is called the Rockwell number and this is read directly on the dial. There are two scales on the dial: " $\mathrm{C}$ " scale which is used with the cone and " $\mathrm{B}$ " scale which is used with the ball.

\footnotetext{
1 A complete list of references and the account of the principal results obtained will be found in "Die Brinellsche Kugeldruckprobe," by P. W. Döhmer, pp. 15-35; Berlin; 1925.

${ }^{2}$ For a description of the Rockwell hardness tester see Automotive.Manufacturer, vol. 62, No. 5, August, 1920.
} 
For the same material the Rockwell B number is different numerically from the Rockwell $\mathrm{C}$ number and neither of them is the same as the Brinell number. Often materials engineers wish to compare the hardness of two materials knowing the Brinell number of one and the Rockwell number of the other. It is also sometimes desirable to be able to compare the indentation hardness of two materials, for one of which the Rockwell B number, and for the other, the Rockwell C number, are known.

The indenting tools, the loads, and the methods of measuring the indentation in Brinell and Rockwell machines are so different that no accurate conversion formula for all classes of materials can be expected to exist. Nevertheless, in general, materials giving relatively small indentations for one type of indenting tool give relatively small indentations with other types of indenting tool and other magnitudes of load. Therefore measurements made with one tool or load may within certain limits of accuracy be used to estimate the result which would be obtained with another, and, in addition, for ferrous materials at least, materials having high tensile strengths have been found to have relatively small indentations (high indentation numbers) and vice versa.

\section{THE PURPOSE OF INVESTIGATION}

The purpose of this investigation was (1) to compare, for a large number of different materials, the different Rockwell numbers with the Brinell numbers and with tensile strengths and to find, if practicable, analytical expressions for the relations between them; (2) to determine the limits of accuracy within which one of these numbers might be used to estimate the value of another or the tensile strength of the material.

\section{ACKNOWLEDGMENTS}

The materials which were used in these tests were contributed by the following manufacturers: Aluminum Co. of America, American Magnesium Corporation, Raritan Copper Works, Chase Metal Works, American Brass Co., Riverside Metal Works, International Nickel Co., Union Drawn Steel Co., Colonial Steel Co., American Rolling Mills Co., Central Steel Co., Halcomb Steel Co., Firth Sterling Steel Co., and Carpenter Steel Co.

The metallurgical division of this bureau has kindly permitted the use of their data on Rockwell and Brinell numbers and on tensile strength for a great variety of steels. ${ }^{3}$ These data were utilized in

\footnotetext{
${ }^{3}$ See the forthcoming Technologic Paper of the Bureau of Standards entitled, "Rough Turning With Particular Reference to the Steel Cut," by H. J. French and T. G. Diggs. The Rockwell and the Brinell numbers on hard steels (Brinell number greater than 400) were obtained on samples (see Table 7, samples I9D to I16B) used by Dr. H. W. Gillett, chief, metallurgical division, Bureau of Standards, in his work on molybdenum and cerium steels. The chemical composition, heat treatment, and other data for theso steels will be found in the book Molybdenum, Cerium and Related Alloy Steels, by H. W. Gillett and E. L. Mack; 1925.
} 
order to check the semiempirical formulas previously obtained on other materials and in order to prepare the tables of average errors of these formulas, which is only possible when a large number of observations are available. Credit is due to Dr. L. B. Tuckerman ${ }^{4}$ for his many valuable suggestions.

\section{MATERIALS}

Both ferrous and nonferrous materials were used in this investigation. The chemical composition, condition, and the tensile properties of the materials are given in Table 1 . The tensile tests were made on A. S. T. M. Standard specimens ( 0.500 inch diameter, 2-inch gauge length.)

The surface of most of the specimens was machined before the hardness numbers were obtained. Some of the nonferrous materials were not machined, but check tests made on these specimens did not show any appreciable difference between the Brinell or the Rockwell numbers obtained on the original surface and on the machined surface.

The materials were obtained in sufficiently large specimens so that a considerable number of different readings could be taken on a single surface.

\footnotetext{
4 Engineer physicist, mechanics and sound division, Bureau of Standards.
} 







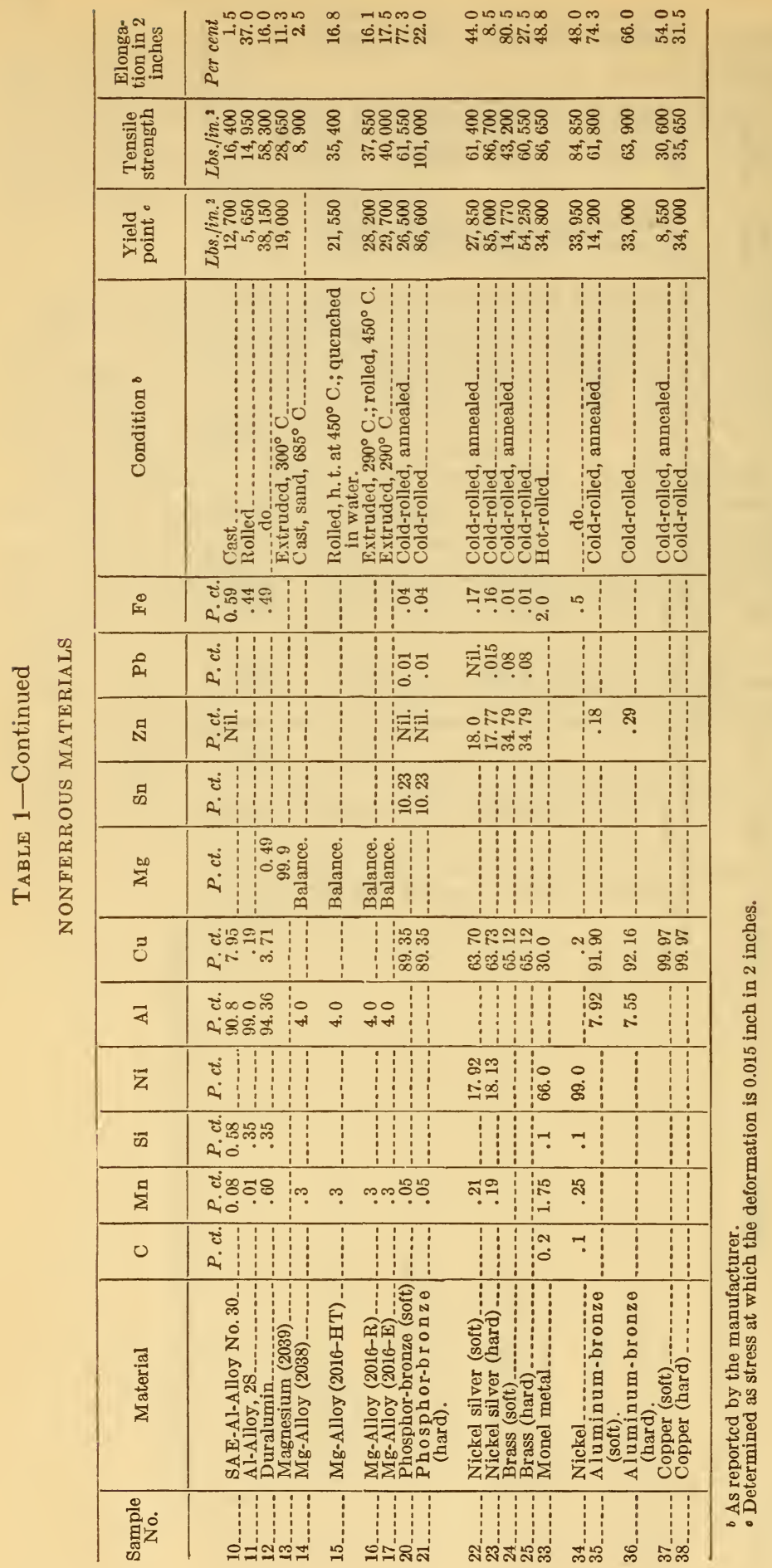



Technologic Papers of the Bureau of Standards, Vol. 21

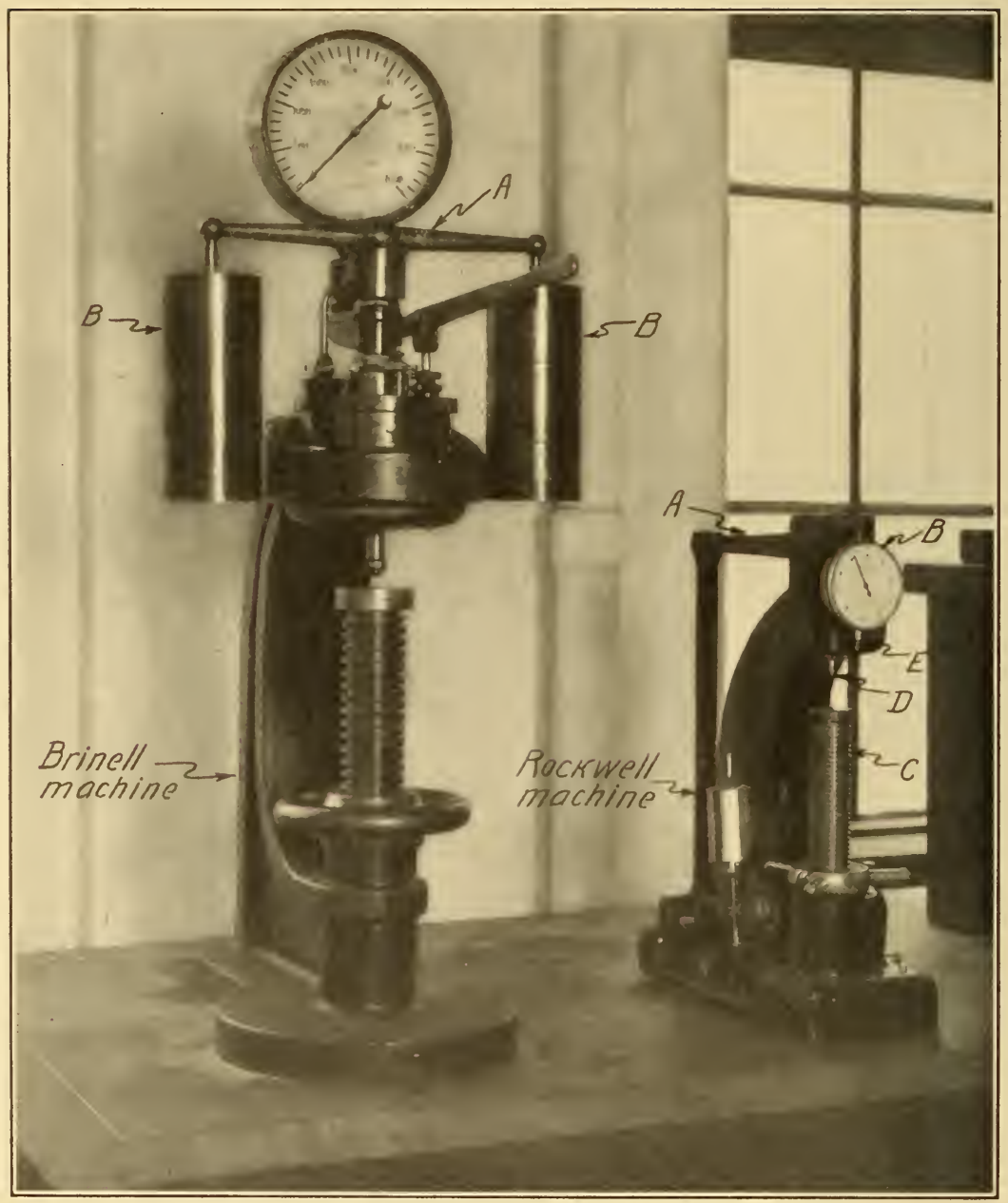

Fig. 1.-The Brinell and the Rockwell machines in which the tests were marle 
The Rockwell indentations were made between and near the Brinell indentations so as to represent the indentation hardness of the same portions of sample in each test.

\section{APPARATUS}

All Brinell tests were made in the hydraulic Brinell machine shown in Figure 1. This machine is provided with a dead-weight relief valve for maintaining the desired load on the ball. This consists of a spherical piston, accurately fitted (without packing) to a cylinder which is connected with the pressure chamber. This piston carries a crossbar, $A$, and weights, $B$. The maximum pressure is limited by the weights and, when this pressure is reached, the piston rises in the cylinder. The load remains constant as long as the piston "fioats."

A ball $10 \mathrm{~mm}$ in diameter was used for all these tests. The load was $3,000 \mathrm{~kg}$ for all metals having Brinell numbers greater than 70 and $500 \mathrm{~kg}$ for metals having lower Brinell numbers. The diameters of the indentations were measured with a Brinell microscope having $0.1 \mathrm{~mm}$ graduations. The readings were estimated to $0.01 \mathrm{~mm}$.

The Rockwell machine used is shown in Figure 1. This machine has a dead-weight lording device which consists of a double lever, $A$, with the total multiplication retio of about 119, and an apparatus (dial $B$ ) for measuring the depth of indentation. The " $\mathrm{C}$ " scale (cone) on the dial $B$ is graduated to read directly 100 minus the depth of indentation, and the " $\mathrm{B}$ " scale (ball) is graduated to read 130 minus the depth of indentation, both in units of $0.002 \mathrm{~mm}$ (about 0.00008 inch). It is evident that the Rockwell number so defined is the higher the smaller the indentation.

The specimen is placed on the table of the elevating screw, $C$, and forced against the indenting tool, $D$, until the so-called "minor" load of $10 \mathrm{~kg}$ is applied. This load is obtained by the compression of a helical spring placed in the head of the machine, and is indicated by a mark on the plunger, $E$. The dial is then set to zero and the "major" load gradually applied. With the increase of load the indenting tool sinks into the specimen, and this is indicated by the movement of an arrow on the dial. When the load on the specimen reaches its maximum value (100 kg for ball and $150 \mathrm{~kg}$ for cone), this is indicated by a sudden change of rate at which the arrow is traveling.

In this investigation, as soon as the total load reached its maximum value, the major load was removed, leaving the mincr load only.

In the Rockwell machine, different types of penetrating tools are used in conjunction with different loads.

For soft and medium materials a $100 \mathrm{~kg}$ major load and a onesixteenth inch ball and for hard materials a $150 \mathrm{~kg}$ load and a diamond

$14642^{\circ}-27-2$ 
cone having an included angle of $120^{\circ}$ are used. For extremely soft materials a one-eighth inch ball can be used with a $100 \mathrm{~kg}$ load.

In addition to the standard Rockwell tests which are recommended by the manufacturer, it was decided to make other measurements with the Rockwell machine in order to obtain more complete data on the change of Rockwell numbers with the change of load or of indenting tool.

The following measurements were made in the Rockwell machine (see Table 2):

TABLE 2.-Loads and tools used in Rockwell tests

\begin{tabular}{|c|c|c|c|c|c|}
\hline Indenting tool & Load & $\begin{array}{l}\text { Notation } \\
\text { for Rock- } \\
\text { well No. }\end{array}$ & Indenting tool & Load & $\begin{array}{l}\text { Notation } \\
\text { for Rock- } \\
\text { well No. }\end{array}$ \\
\hline $\begin{array}{l}1 / 16 \text { inch }(1.59 \mathrm{~mm}) \text { ball. } \\
1 / 8 \text { inch }(3.18 \mathrm{~mm}) \text { ball. }\end{array}$ & $\left\{\begin{array}{c}\mathrm{kg} \\
100 \\
60 \\
100\end{array}\right.$ & $\begin{array}{c}{ }_{100} R_{\mathrm{Bl} / 16} \\
60 R_{\mathrm{Bl} / 16} \\
{ }_{100} R_{\mathrm{Bl} / 8}\end{array}$ & $120^{\circ}$ diamond cono..... & $\left\{\begin{array}{l}\mathrm{kg} \\
150 \\
100 \\
60\end{array}\right.$ & $\begin{array}{l}{ }_{150} R_{\text {o. }} \\
{ }_{100} R_{\mathrm{c}} . \\
{ }_{60} R_{\mathrm{o}} .\end{array}$ \\
\hline
\end{tabular}

a Standard test.

\section{RESULTS OF TESTS}

The results of tests which were used for deriving the basic conversion formulas are given in Table 3 .

TABLE 3.-Brinell and Rockwell numbers of tested metals

[Each value represents an average of at least four determinations]

I. FERROUS METALS

\begin{tabular}{|c|c|c|c|c|c|c|c|}
\hline Sample No. & $B n$ & ${ }_{100} R_{\mathbf{B} 1 / 10}$ & $100 R_{\mathrm{B} 1 / 8}$ & ${ }_{00} R_{\mathrm{B} 1 / 10}$ & ${ }_{150} R_{\text {。 }}$ & ${ }_{100} R_{\text {。 }}$ & ${ }_{00} R_{0}$ \\
\hline $\begin{array}{l}153-\cdots \\
54-\cdots \\
25--.-\end{array}$ & $\begin{array}{l}129 \\
98.4 \\
125 \\
204 \\
225\end{array}$ & $\begin{array}{l}74.0 \\
55.2 \\
68.2 \\
98.9 \\
98.4\end{array}$ & $\begin{array}{r}102.5 \\
91.8 \\
99.1 \\
112.8 \\
113.2\end{array}$ & $\begin{array}{r}99.0 \\
90.1 \\
96.8 \\
111.4 \\
112.0\end{array}$ & $\begin{array}{r}-5.0 \\
-24.0 \\
-6.7 \\
18.4 \\
19.7\end{array}$ & $\begin{array}{l}23.5 \\
80.0 \\
20.0 \\
40.7 \\
42.4\end{array}$ & $\begin{array}{l}42.8 \\
47.7\end{array}$ \\
\hline $\begin{array}{l}45 \\
28- \\
55 \\
67 \\
6\end{array}$ & $\begin{array}{l}232 \\
178 \\
248 \\
367 \\
224\end{array}$ & $\begin{array}{r}97.2 \\
85.3 \\
97.6 \\
111.6 \\
96.4\end{array}$ & $\begin{array}{l}114.2 \\
106.2 \\
113.5 \\
121.4 \\
113.1\end{array}$ & $\begin{array}{l}112.2 \\
105.0 \\
112.5 \\
120.2 \\
111.7\end{array}$ & $\begin{array}{l}22.0 \\
7.5 \\
22.5 \\
41.9 \\
20.0\end{array}$ & $\begin{array}{l}42.5 \\
33.3 \\
42.1 \\
56.8 \\
40.1\end{array}$ & 71.9 \\
\hline $\begin{array}{l}57-\ldots . \\
56 \\
58-\end{array}$ & $\begin{array}{l}339 \\
212 \\
256 \\
268\end{array}$ & $\begin{array}{r}108.0 \\
93.8 \\
102.3 \\
104.6\end{array}$ & $\begin{array}{l}118.8 \\
112.5 \\
116.2 \\
117.1\end{array}$ & $\begin{array}{l}117.4 \\
110.2 \\
114.6 \\
116.2\end{array}$ & $\begin{array}{l}36.8 \\
18.6 \\
27.7 \\
28.4\end{array}$ & $\begin{array}{l}52.1 \\
40.2 \\
46.0 \\
48.1\end{array}$ & $\begin{aligned} 68.5 \\
-64 .-1 \\
65.8\end{aligned}$ \\
\hline $\begin{array}{l}9 \\
8 \\
89 \\
59 \\
\text { SS. }\end{array}$ & $\begin{array}{l}204 \\
226 \\
230 \\
225\end{array}$ & $\begin{array}{l}92.6 \\
96.8 \\
96.8 \\
98.0\end{array}$ & $\begin{array}{l}112.0 \\
112.8 \\
112.1 \\
114.0\end{array}$ & $\begin{array}{l}109.5 \\
111.1 \\
111.7 \\
112.3\end{array}$ & $\begin{array}{l}16.5 \\
22.2 \\
19.1 \\
21.6\end{array}$ & $\begin{array}{l}39.0 \\
42.0 \\
41.2 \\
42.2\end{array}$ & 62.1 \\
\hline & $\begin{array}{l}239 \\
156\end{array}$ & $\begin{array}{l}98.0 \\
79.0\end{array}$ & 112.6 & 111.9 & 21.2 & 42.0 & \\
\hline 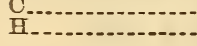 & $\begin{array}{l}192 \\
216\end{array}$ & $\begin{array}{l}94.0 \\
94.0\end{array}$ & & & & & \\
\hline
\end{tabular}


TABLE 3.-Brinell and Rockwell numbers of tested metals-Continued

II. NONFERROUS MÉTALS

\begin{tabular}{|c|c|c|c|c|c|c|c|}
\hline Sample No. & $B n=$ & $100 R_{\mathrm{B} 1 / 16}$ & ${ }_{100}^{\prime} R_{\mathrm{B} 1 / 8}$ & ${ }_{60} R_{\mathrm{B} 1 / 16}$ & ${ }_{150} R_{\text {。 }}$ & ${ }_{100} R_{0}$ & ${ }_{60} R_{0}$ \\
\hline 10 & $\begin{array}{r}67.7 \\
28.0 \\
123 \\
43.5 \\
43.4\end{array}$ & $\begin{array}{c}25 \\
\text { Too soft. } \\
69.9 \\
\text { Too soft. } \\
-40\end{array}$ & $\begin{array}{l}81 \\
-3 \\
98.1 \\
46 \\
42\end{array}$ & $\begin{array}{l}77 \\
-25 \\
97.2 \\
34 \\
39\end{array}$ & $\begin{array}{r}\text { About-35. } \\
\text { Too soft. } \\
-8.8 \\
\text { Too soft. } \\
\text { Too soft. }\end{array}$ & $\begin{array}{c}\quad 0 \\
\text { Too soft. } \\
19.3 \\
\text { Too soft. } \\
\text { Too soft. }\end{array}$ & $\begin{array}{c}\text { About } 35 . \\
-18 \\
48.1 \\
5 \\
\text { Too soft. }\end{array}$ \\
\hline $\begin{array}{l}15 \\
16 \\
17 \\
20 \\
21\end{array}$ & $\begin{array}{r}50.3 \\
56.8 \\
61.3 \\
95.4 \\
218\end{array}$ & $\begin{array}{c}-15 \\
4.1 \\
20 \\
51.1 \\
98.3\end{array}$ & $\begin{array}{r}59.6 \\
70.1 \\
75.0 \\
86.8 \\
114.3\end{array}$ & $\begin{array}{r}53.5 \\
62.7 \\
70.4 \\
85.0 \\
112.4\end{array}$ & $\begin{array}{l}\text { Too soft. } \\
\text { Too soft. } \\
\text { Too soft. } \\
-29 \\
21.8\end{array}$ & $\begin{array}{r}\text { Too soft. } \\
\text { Too soft. } \\
-12 \\
6.0 \\
42.0\end{array}$ & $\begin{array}{l}15 \\
22.1 \\
25.5 \\
38.0 \\
62.4\end{array}$ \\
\hline $\begin{array}{l}22 \\
23 \\
24 \\
25 \\
33\end{array}$ & $\begin{array}{l}103 \\
174 \\
151.4 \\
126 \\
147\end{array}$ & $\begin{array}{r}58.4 \\
88.8 \\
9.5 \\
72.8 \\
78.5\end{array}$ & $\begin{array}{r}90.7 \\
110.7 \\
66.1 \\
102.1 \\
101.9\end{array}$ & $\begin{array}{r}90.2 \\
108.1 \\
64.9 \\
99.0 \\
100.5\end{array}$ & $\begin{array}{r}-21 \\
13.1 \\
\text { Too soft. } \\
-3.0 \\
1.0\end{array}$ & $\begin{array}{r}12.3 \\
36.3 \\
\text { Too soft. } \\
22.8 \\
27.1\end{array}$ & $\begin{array}{l}41.6 \\
57.6 \\
23.4 \\
49.5 \\
52.5\end{array}$ \\
\hline $\begin{array}{l}34 \\
35 \\
36 \\
38\end{array}$ & $\begin{array}{r}132 \\
72.0 \\
110.6 \\
42.0 \\
75\end{array}$ & $\begin{array}{r}74.3 \\
36.5 \\
65.2 \\
-39 \\
33.9\end{array}$ & $\begin{array}{l}99.0 \\
76.7 \\
93.9 \\
35.6 \\
86.5\end{array}$ & $\begin{array}{l}98.6 \\
76 \\
93.1 \\
35.0 \\
79.2\end{array}$ & $\begin{array}{c}-6.1 \\
\text { Too soft. } \\
-15.2 \\
\text { Too soft. } \\
\text { - } 35\end{array}$ & $\begin{array}{r}21.8 \\
-6.5 \\
14.9 \\
\text { Too soft. } \\
0\end{array}$ & $\begin{array}{l}48.2 \\
30.0 \\
43.6 \\
1.6 \\
36\end{array}$ \\
\hline
\end{tabular}

1 For $3,000 \mathrm{~kg}$ load $B n=65$.

\section{THEORETICAL RELATIONSHIPS}

The Brinell number is defined as the ratio of the load to the surface area of the indentation. If this ratio were a constant of the material independent of the indenting tool and of the load, then, applying this definition to the Rockwell test, the following expressions would be all equal:

$$
\begin{aligned}
B n_{3000}=B n_{500} & =\frac{C_{1}}{130-{ }_{100} R_{\mathrm{B} 1 / 16}}=\frac{C_{2}}{130-{ }_{100} R_{\mathrm{B} 1 / 8}}=\frac{C_{3}}{130-{ }_{60} R_{\mathrm{B} 1 / 16}} \\
& =\frac{C_{4}}{\left(100-{ }_{150} R_{\mathrm{c}}\right)^{2}}=\frac{C_{5}}{\left(100-{ }_{100} R_{\mathrm{c}}\right)^{2}}=\frac{C_{6}}{\left(100-{ }_{60} R_{\mathrm{c}}\right)^{2}}
\end{aligned}
$$

The constants $C_{1}, C_{2}, C_{3}, C_{4}, C_{5}$, and $C_{6}$ are computed from the load and the dimensions of the indenting tool, $R_{\mathrm{B}}$ is Rockwell ball number and $R_{\mathrm{c}}$ is Rockwell cone number. The indexes $1 / 16$ and $1 / 8$ indicate the diameter of ball in inches and the indexes 150,100 , and 60 the load in kg. These relations follow from the fact that the spherical area of a ball indentation $A_{\mathrm{B}}=2 \pi \mathrm{rh}$ and the area of a cone indentation $A_{\mathrm{c}}=C \pi h^{2}$. Here, $r$ is the radius of ball (in $\mathrm{mm}$ ); $h$, depth of indentation due to the major load; and $C$ a numerical constant depending upon the angle of the cone. According to the definition of the Rockwell number $h=a\left(130-R_{\mathrm{B}}\right)$ for ball and $h=a\left(100-R_{\mathrm{c}}\right)$ for cone where $a$ is the unit of graduation of the dial $(0.002 \mathrm{~mm})$. Therefore, $A_{\mathrm{B}}=2 \pi r a\left(130-R_{\mathrm{B}}\right)$ and $A_{\mathrm{c}}=C \pi a^{2}\left(100-R_{\mathrm{c}}\right)^{2}$. From these equations the following linear relationships between the Rockwell numbers can be derived:

$$
\begin{gathered}
{ }_{100} R_{\mathrm{B} 1716}=K_{1} \times{ }_{100} R_{\mathrm{B} 1 / 8}+K_{2}=K_{3} \times_{60} R_{\mathrm{B} 1 / 16}+K_{4} ; \\
{ }_{150} R_{\mathrm{c}}=K_{5} \times_{100} R_{\mathrm{c}}+K_{6}=K_{7} \times_{60} R_{\mathrm{c}}+K_{8} .
\end{gathered}
$$


The theoretical relationships given in the series of equations (1) were computed for various loads and indenting tools, which are used in the Rockwell machine. Because of the minor load of $10 \mathrm{~kg}$ which is used in the Rockwell test, it was necessary to make a correction for this minor load. The nature of this correction is explained below.

In a ball test the area of indentation is proportional to the depth. Therefore, if $h$ is the increase of the depth of indentation due to an increment of load between minor and major load, the total area of indentation due to the total load of $P \mathrm{~kg}$ will be:

$$
A_{\mathrm{B}}=2 \pi r\left(h+h \times \frac{10}{P}\right)=2 \pi r h\left(\frac{P+10}{P}\right)
$$

and the average pressure per unit area of indentation is

$$
\frac{P}{A_{\mathrm{B}}}=\frac{P^{2}}{2 \pi r h(P+10)}
$$

But the depth of indentation $h=\left(130-R_{\mathrm{B}}\right) \times a$, where $a$ is the value of one division of the dial in the Rockwell machine. Theoretically,

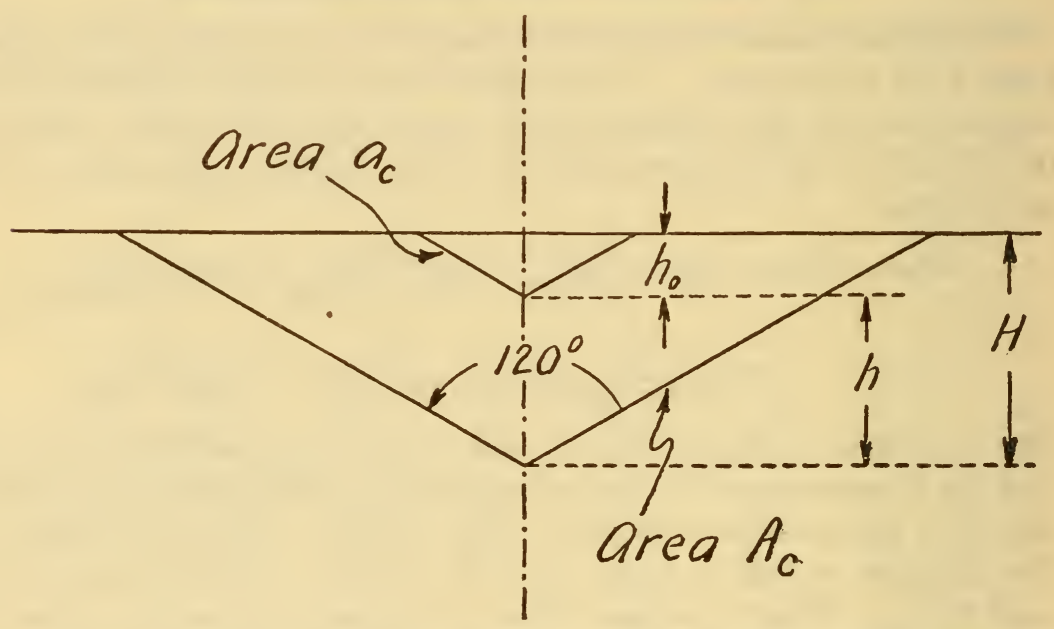

FIg. 2.-Rockwell cone indentations due to the minor and major loads

the average pressure on the surface of indentation may be called the Brinell number. Therefore, for a Rockwell ball test

$$
B n=\frac{P^{2}}{2 \pi r(P+10) \times\left(130-R_{\mathrm{B}}\right) \times a}
$$

For a cone the area of indentation is proportional to the square of the depth. For a $120^{\circ}$ cone (see fig. 2) $\frac{A_{\mathrm{c}}}{a_{\mathrm{c}}}=\frac{H^{2}}{h_{\mathrm{o}}{ }^{2}}$ where $h_{\mathrm{o}}$ is the depth of indentation for a minor load of $10 \mathrm{~kg}$ and $H$ the total depth of inden- 
tation. On the other hand, theoretically the area of indentation is proportional to the load $\frac{A_{\mathrm{c}}}{a_{\mathrm{c}}}=\frac{P}{10}$. Therefore

hence

$$
\frac{P}{10}=\frac{H^{2}}{h_{0}^{2}} \cdot H=h_{0}+h \quad \frac{P}{10}=\frac{\left(h_{0}+h\right)^{2}}{h_{0}{ }^{2}}
$$

$$
\begin{gathered}
h_{\mathrm{o}}=\frac{h}{\sqrt{\frac{P}{10}-1}} \\
H=h_{\mathrm{o}}+h=h \frac{\sqrt{\frac{P}{10}}}{\sqrt{\frac{P}{10}-1}}=\frac{\left(100-{ }_{\mathrm{p}} R_{\mathrm{c}}\right) \times a}{\sqrt{\frac{P}{10}-1}} \sqrt{\frac{P}{10}}
\end{gathered}
$$

where ${ }_{\mathrm{P}} R_{\mathrm{c}}$ is the Rockwell number for cone and for a load $P$. Theoretically $B n=\frac{P}{A_{\mathrm{c}}}$. But for a $120^{\circ}$ cone, $A_{\mathrm{c}}=10.87 H^{2}$. Therefore

$$
B n=\frac{P \times\left(\sqrt{\frac{P}{10}}-1\right)^{2}}{10.87 \times\left(100-{ }_{\mathrm{P}} R_{\mathrm{c}}\right)^{2} \times a^{2} \times \frac{P}{10}}
$$

or

$$
B n=\frac{(\sqrt{P}-\sqrt{10})^{2}}{10.87\left(100-{ }_{\mathrm{P}} R_{\mathrm{c}}\right)^{2} \times a^{2}}
$$

\begin{tabular}{|c|c|c|}
\hline \multicolumn{2}{|l|}{ Rockwell } & \multirow{2}{*}{ Theoretical relation } \\
\hline Tool & Load & \\
\hline $\begin{array}{l}1 / 16 \text { inch }(1.59 \mathrm{~mm}) \text { ball (standard) } \\
1 / 8 \text { inch }(3.18 \mathrm{~mm}) \text { ball (standard) } \\
1 / 16 \text { inch }(1.59 \mathrm{~mm}) \text { ball } \\
120^{\circ} \text { cone (standard) } \\
120^{\circ} \text { cone. }\end{array}$ & $\begin{array}{r}k g \\
100 \\
100 \\
60 \\
150 \\
100 \\
60\end{array}$ & $\begin{array}{l}B n=\frac{9,120}{130-100 R_{\mathrm{B} 1 / 16}} \\
B n=\frac{4,560}{130-100 R_{\mathrm{B} 1 / 8}} \\
B n=\frac{5,170}{130-60 R_{\mathrm{B} 1 / 16}} \\
B n=\frac{1,900,000}{\left(100-1,10 R_{\mathrm{c}}\right)^{2}} \\
B n=\frac{1,076,000}{\left(100-100 R_{\mathrm{c}}\right)^{2}} \\
B n=\frac{483,000}{\left(100-60 R_{\mathrm{c}}\right)^{3}}\end{array}$ \\
\hline
\end{tabular}

Using equations (2) and (3) the theoretical relations between the Brinell and the Rockwell numbers were found for various loads and indenting tools in the Rockwell machine and are given in Table 4.

TABLE 4.-Theoretical relations between the Rockwell and Brinell numbers 
From these the following relationships can be derived:

$$
\begin{aligned}
& { }_{100} R_{\mathrm{B} 1 / 16}=2 \times_{100} R_{\mathrm{B} 1 / 8}-130 \\
& { }_{100} R_{\mathrm{B} 1 / 16}=1.764 \times \times_{60} R_{\mathrm{B} 1 / 16}-99.3 \\
& { }_{150} R_{\mathrm{c}}=1.328 \times{ }_{100} R_{\mathrm{c}}-32.8 \\
& { }_{150} R_{\mathrm{c}}=1.983 \times{ }_{60} R_{\mathrm{c}}-98.3 \\
& { }_{100} R_{\mathrm{B} 11_{16}}=130-\frac{\left(100-{ }_{150} R_{\mathrm{c}}\right)^{2}}{208.3} \\
& { }_{150} R_{\mathrm{c}}=100-\sqrt{27,080-208.3 \times{ }_{100} R_{\mathrm{B} 1716}}
\end{aligned}
$$

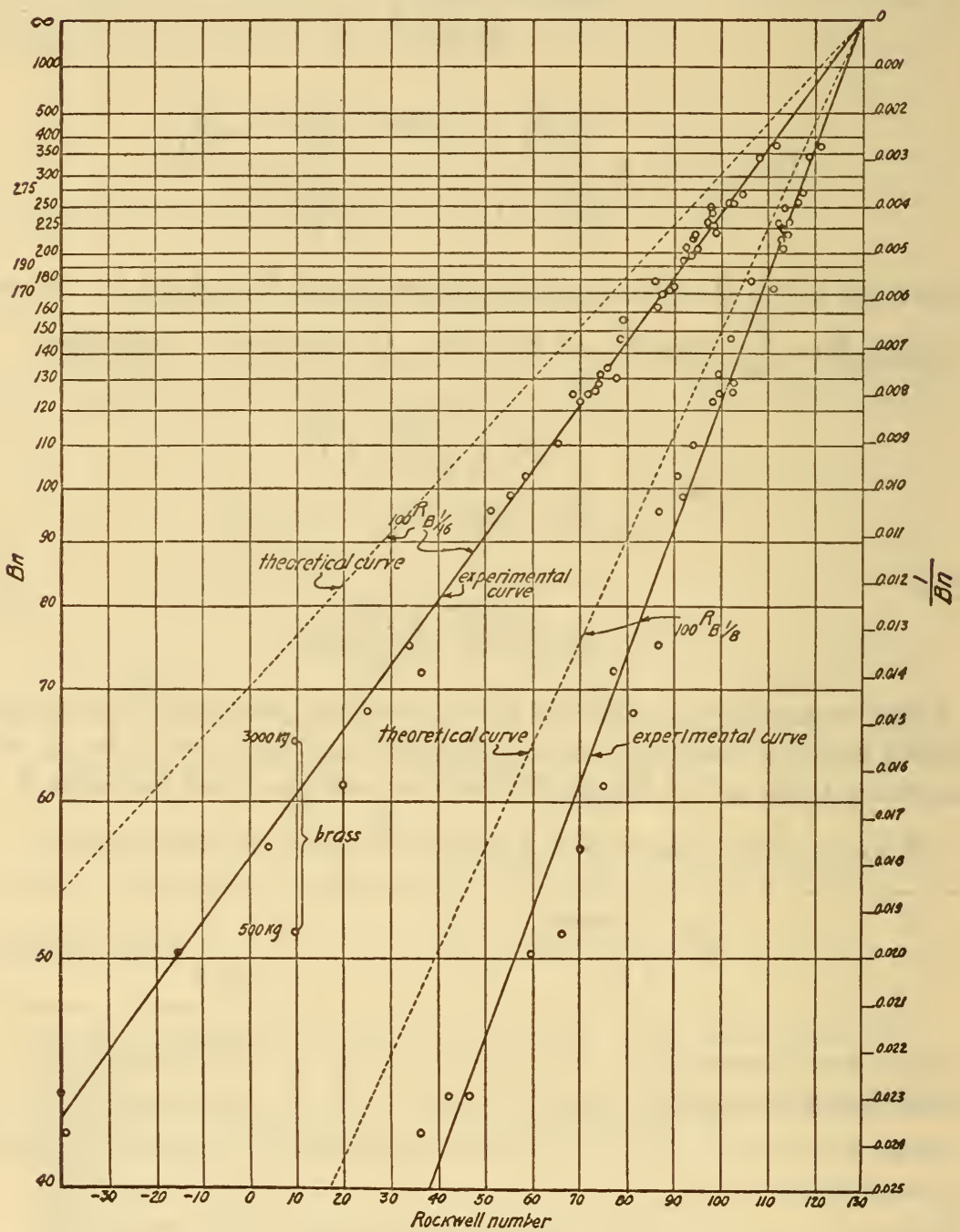

FIG. 3.-Relations between the Brinell and the_Rockwell ball numbers

\section{EXPERIMENTAL RELATIONSHIPS}

The experimental results are given in Table 3 and are shown graphically in Figures 3, 4, and 5.5 Each point on these diagrams 
represents an average of at least 3 experimental determinations. It is evident that there is an approximately straight line relation between the Rockwell ball number and $\frac{1}{B n}$ on one hand and between the Rockwell cone number and $\sqrt{\frac{1}{B n}}$ on the other hand. As was to be expected, the theoretical relations noted above were not verified. However, as can be seen from Figures 3 and 4 the curves, although

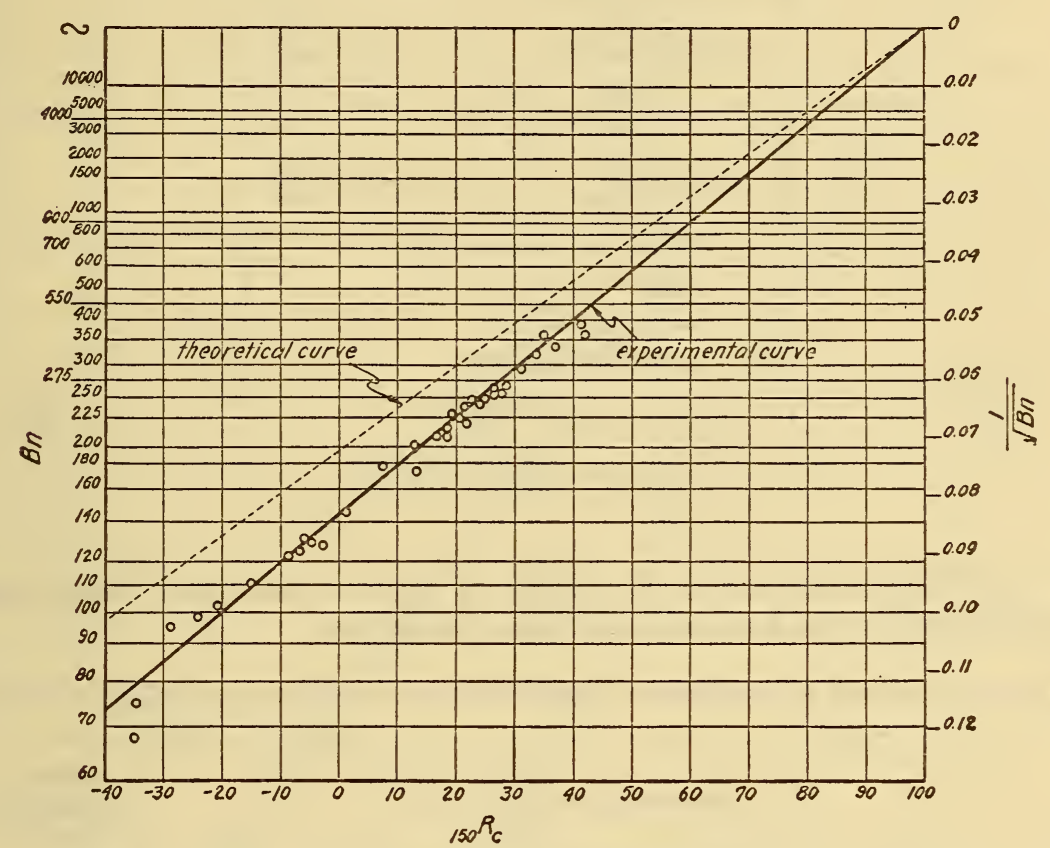

FrG. 4.-Relation between the Brinell and the Rockwell cone numbers

departing from the theoretical straight lines, are fairly close to straight lines. This suggested that considerably closer agreement would be found by treating the constants of the equations given in Table 4 as empirical constants to be determined from the observations. These coefficients were determined by drawing straight lines representing the average relation between the Rockwell and Brinell numbers (figs. 3 and 4 ).

This method of deriving the experimental coefficients was carried through for all other relationships, and the values of these coefficients are found in Table 5 . 
TABLE 5.-Experimental relationships between the Brinell and Rockwell numbers

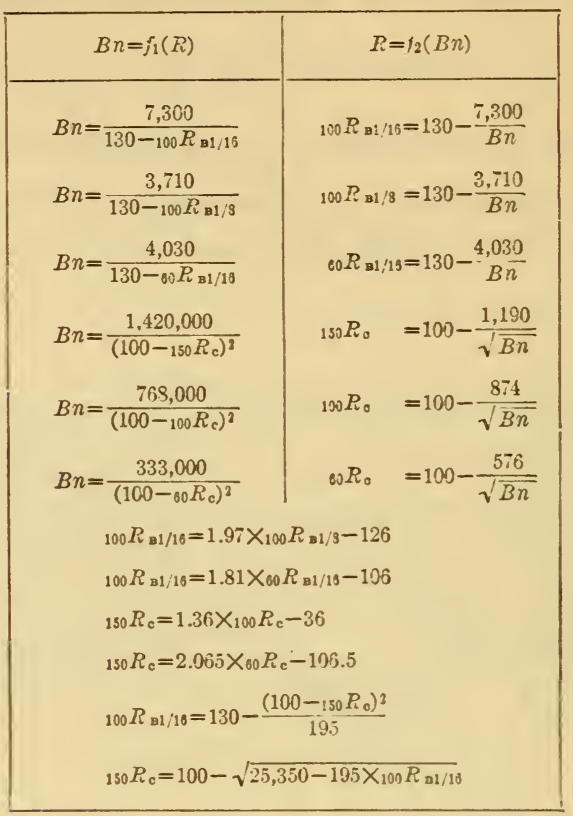

In Table 6 are given the ratios of experimental and theoretical coefficients in the formulas for Brinell numbers.

TABLE 6.-Ratios of experimental and theoretical coefficients for Brinell numbers

\begin{tabular}{|c|c|}
\hline Relationship between- & $\begin{array}{l}\text { Ratio of } \\
\text { experimental } \\
\text { coefficients to } \\
\text { theoretical }\end{array}$ \\
\hline 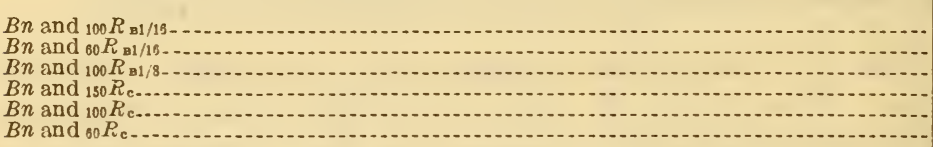 & $\begin{array}{l}0.802 \\
.780 \\
.813 \\
.743 \\
.715 \\
.688\end{array}$ \\
\hline
\end{tabular}

In all cases the theoretical equation would give a higher value of Brinell number than the experimental equation.

This discrepancy between the experimental and theoretical relations may in part be explained in the following way: From the equation

we have

$$
B n=\frac{C^{\prime}}{130-R_{\mathrm{B}}} \text { or } B n=\frac{C^{\prime \prime}}{\left(100-R_{\mathrm{c}}\right)^{2}}
$$

$$
C^{\prime}=B n \times\left(130-R_{\mathrm{B}}\right) \text { and } C^{\prime \prime}=B n \times\left(100-R_{\mathrm{c}}\right)^{2}
$$


(1) On one hand, the elastic deformation of the material and of the indenting tool both have a tendency to make the Rockwell indentation shallower than it would be in a perfectly plastic material, and if the indenting tool did not deform elastically. This makes the

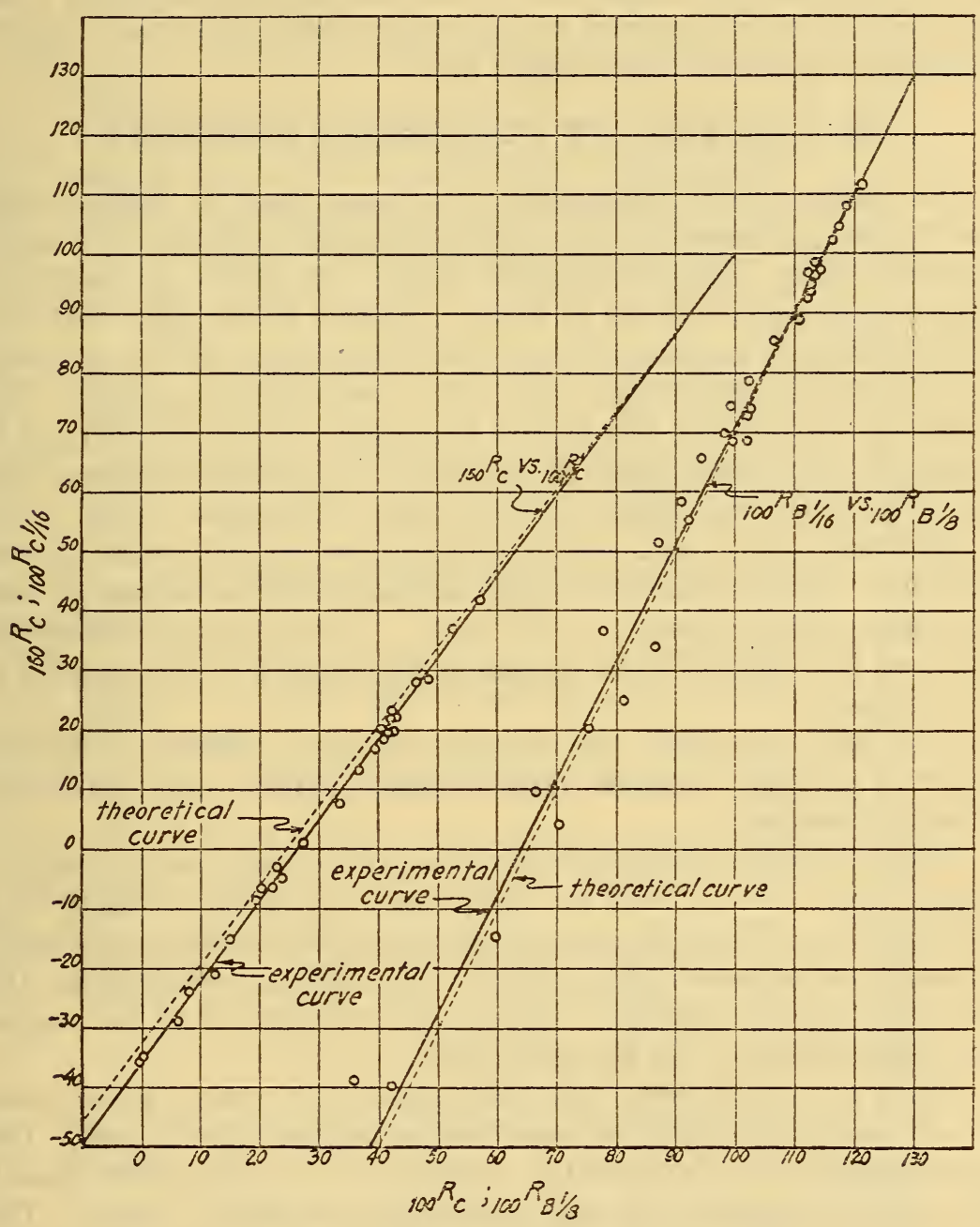

Fig. 5.-Relations between the Rockwell numbers

terms $\left(130-R_{\mathrm{B}}\right)^{6}$ and $\left(100-R_{\mathrm{c}}\right)^{6}$ smaller than they are theoretically. Consequently, $C^{\prime}$ and $C^{\prime \prime}$ ought to be smaller.

(2) On the other hand, the elastic deformation of the Brinell ball results in a larger diameter of indentation and, therefore, in a lower Brinell number. This causes a further decrease of $C^{\prime}$ and $C^{\prime \prime}$. Apparently the ratio of experimental to theoretical coefficients (see

${ }^{6}$ It will be romembered that these terms represent the depth of indentation. 
Table 6) increases with the load. This is what might be expected because the relative effect of elastic deformation becomes smaller with the increase of the total depth of penetration.

The relationships between the different Rockwell numbers are shown graphically in Figure 5. For the same indenting tool these relationships are represented by the straight lines which only slightly differ from the theoretical straight lines.

\section{ACCURACY OF CONVERSION FORMULAS}

The semiempirical relationships which are given in Table 5 were used to compute Brinell numbers from the Rockwell numbers obtained experimentally. These computed values are given in Table $7 .^{7}$ Only exceptionally did any of these computed values differ from the observed Brinell numbers by more than 10 per cent and these exceptional cases are usually for very soft or very hard materials. The average deviation was less than 5 per cent. The few deviations in excess of 5 per cent found in materials of medium hardness were probably caused by the lack of uniformity of material.

Consistent results can not be obtained on material which is not uniform. Nonuniformity may be caused by the variations in heat treatment, casehardening, or cold work. Sometimes nonuniformity is caused by segregation in the ingot, particularly if the material is heat treated.

In Table 8 are given the average errors for different ranges of Rockwell numbers. Let us consider these errors for each conversion formula separately.

(a) $B n$ computed from ${ }_{100} R_{\mathrm{B} 1 / 16}$ : It is evident that for the range of ${ }_{100} R_{\mathrm{Bi} / 16}$ from -40 to +35 the errors are considerably greater than above ${ }_{100} R_{\mathrm{B} 1 / 16}=35$ and that above that value they remain apparently constant up to about ${ }_{100} R_{\mathrm{B} 1116}=105$. For ${ }_{100} R_{\mathrm{B} 1 / 16}$ greater than 105 the errors increase rapidly. This is undoubtedly due to the permanent deformation of the Rockwell ball.

(b) $B n$ computed from ${ }_{150} R_{\mathrm{c}}$ : Here again the errors of computed $B n$ are much greater for soft materials up to about 100 Brinell. The errors then become apparently constant up to about 400 Brinell. For harder materials ${ }_{150} R_{\mathrm{c}}$ will invariably give higher values. The discrepancies between the computed and the actual values of Brinell numbers become so great that a correction is necessary to make any comparison at all.

\footnotetext{
7 This table contains not only the results which were used to derive the basic conversion formulas and which appear in Table 3, but it contains also a large number of values which were obtained in the section of thermal metallurgy of the metallurgical division of this_bureau.
} 


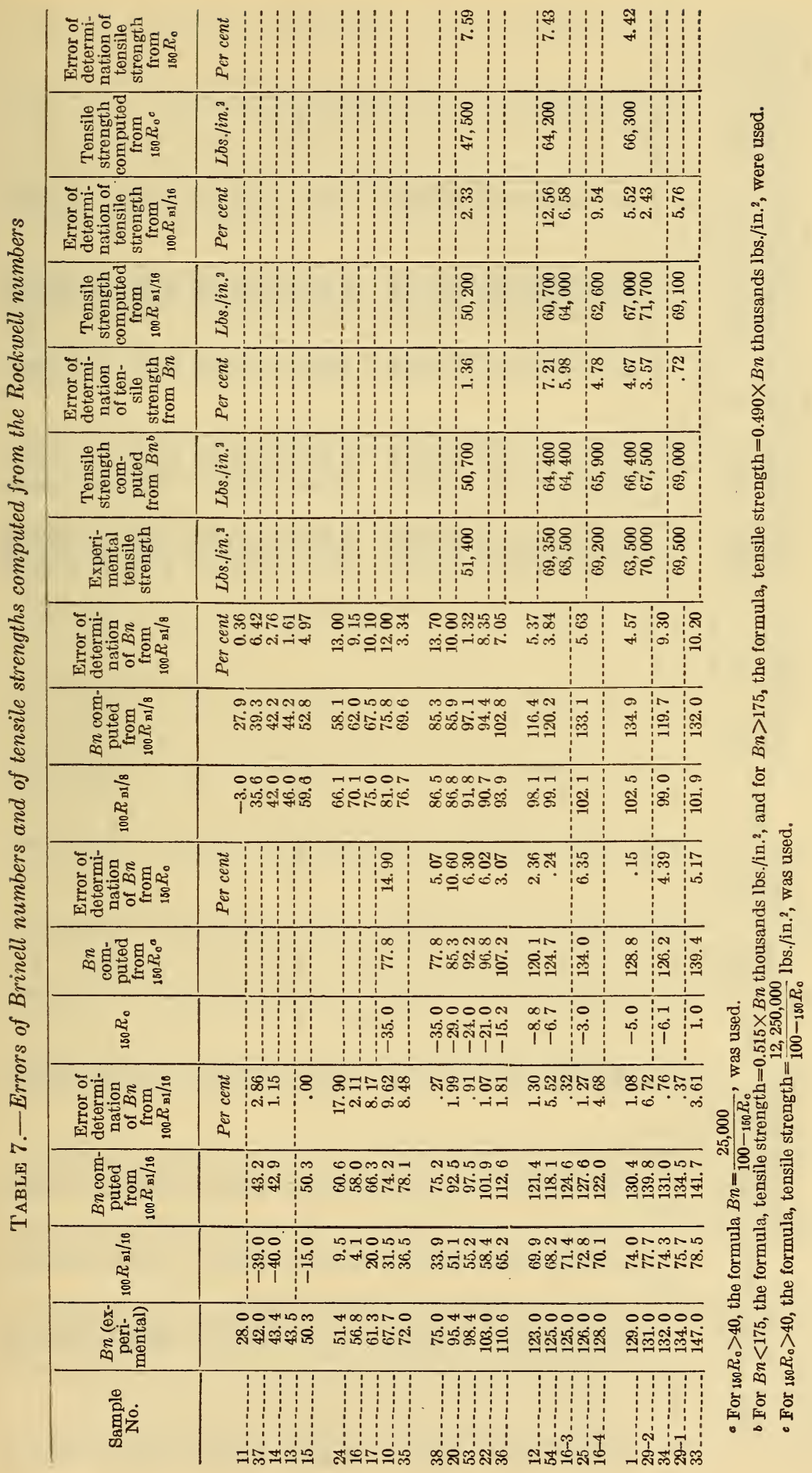




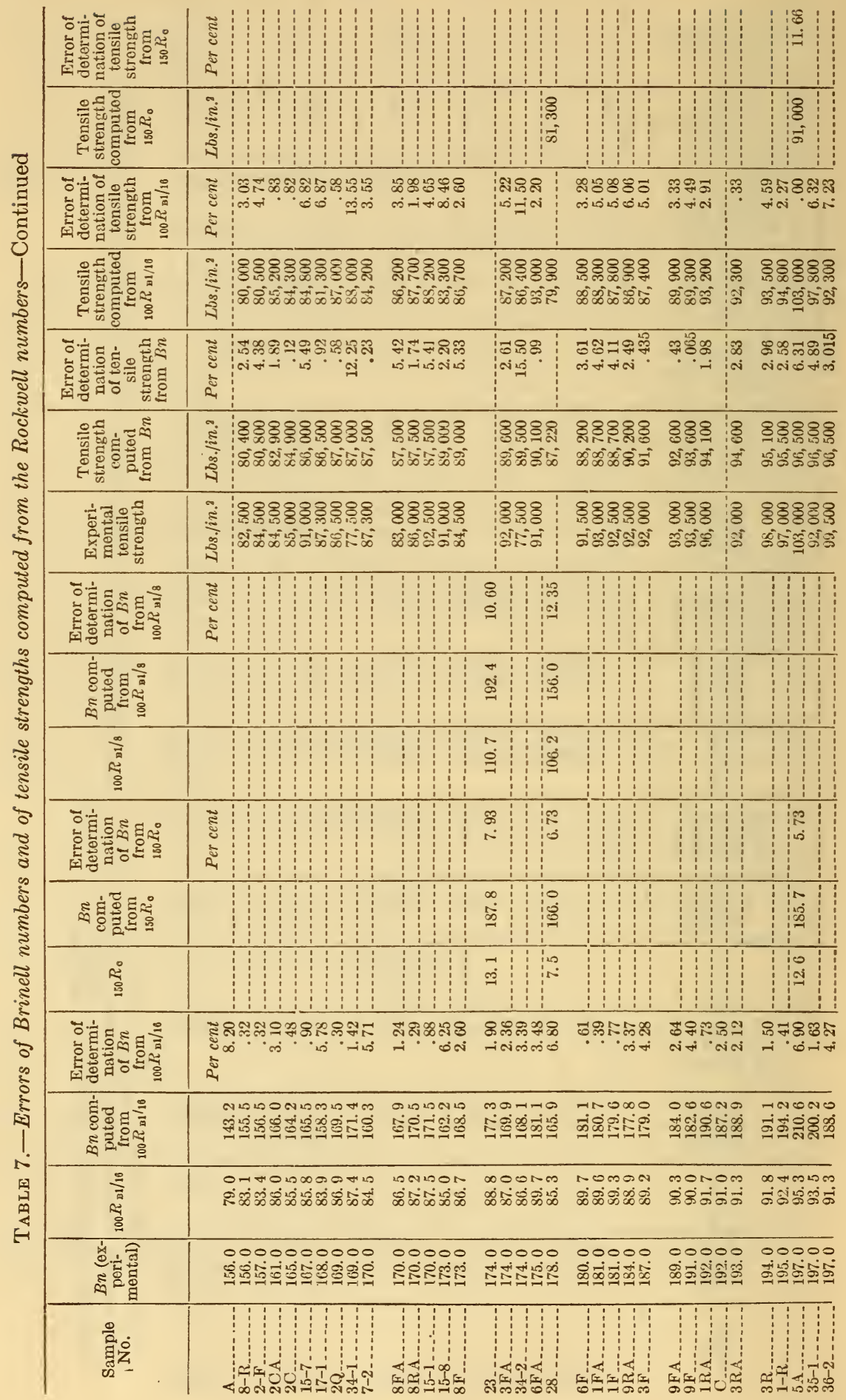




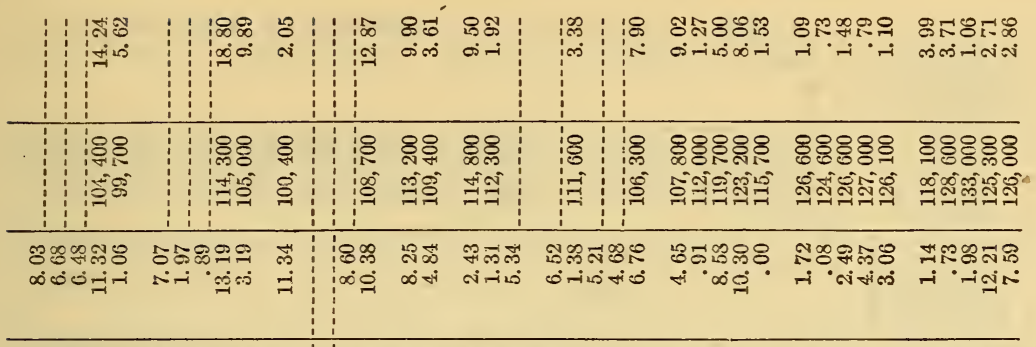

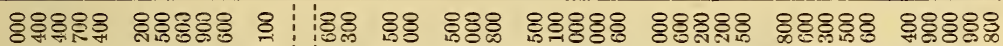

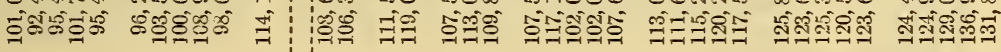

\begin{tabular}{|c|c|c|c|c|c|c|c|c|}
\hline 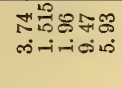 & 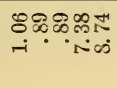 & * & 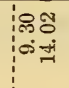 & 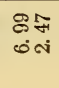 & 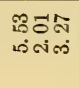 & 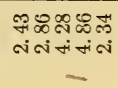 & 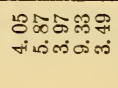 & 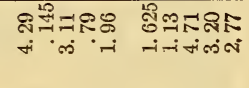 \\
\hline
\end{tabular}

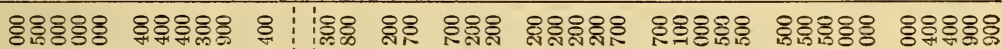

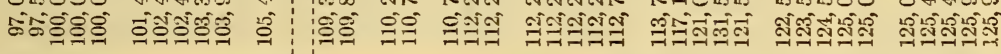

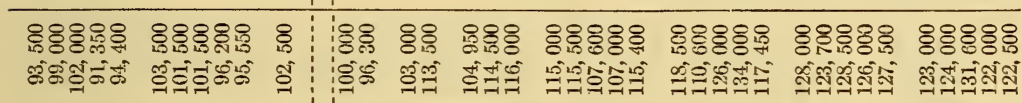

\begin{tabular}{|c|c|c|c|c|c|c|c|c|c|c|c|c|}
\hline $\begin{array}{l}\text { : } \\
100 \\
100 \\
10\end{array}$ & in & & : & is & $\Rightarrow$ & ; & ! & $\begin{array}{l}\infty \\
\infty \\
\infty\end{array}$ & 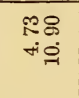 & is & & $\begin{array}{l}8 \\
10 \\
10\end{array}$ \\
\hline 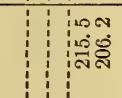 & 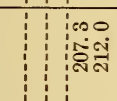 & & is & $\begin{array}{l}0 \\
0 \\
\tilde{B} \\
\end{array}$ & $\begin{array}{l}\text { i } \\
\text { ๙ิ }\end{array}$ & & & n & $\begin{array}{l}\text { 우 } \\
\text { สี่ี่ }\end{array}$ & : & & : \\
\hline $\begin{array}{l}\infty 0 \\
\text { s่ง } \\
\exists\end{array}$ & 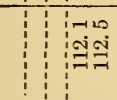 & & $\infty_{\substack{\infty \\
=}}^{\infty}$ & $\underset{\sim}{=1}$ & \begin{tabular}{l|l}
$\circ$ & \\
$\stackrel{J}{二}$ &
\end{tabular} & & & 水 & $\begin{array}{l}N \infty \\
\dddot{m} \infty \\
\Rightarrow=\end{array}$ & $\begin{array}{l}0 \\
1 \\
=0\end{array}$ & & $\begin{array}{l}1 \\
0 \\
0 \\
= \\
=\end{array}$ \\
\hline : & $\begin{array}{l}\infty \\
\infty\end{array}$ & $\begin{array}{l}10 \\
i ⿱ 乛 \\
+i\end{array}$ & : & $\infty$ & $\begin{array}{l}\text { సล } \\
\text { กิ- }\end{array}$ & $\begin{array}{l}\text { \&ి } \\
\text { i. }\end{array}$ & สิ & 18 & $\begin{array}{l}\text { \&ละ } \\
\text { +่ }\end{array}$ & 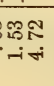 & 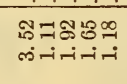 & 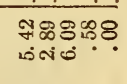 \\
\hline 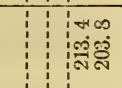 & 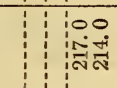 & ๙ & חึ & : & $\begin{array}{l}\text { พ๐ } \\
\text { ฟึกิ }\end{array}$ & 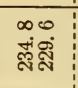 & : & i⿱ & 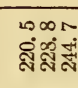 & $\begin{array}{l}\infty \infty \\
-10 \\
-\infty\end{array}$ & 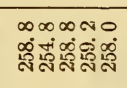 & 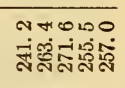 \\
\hline : & 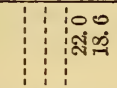 & $\infty$ & : & : & $\begin{array}{l}\text { ON } \\
\text { הंत्ल }\end{array}$ & $\begin{array}{l:l}\text { Nm } \\
\text { มี่ }\end{array}$ & : & פּ & $\begin{array}{l}\text { 시 } \\
\text { వైส }\end{array}$ & $\begin{array}{l}\text { का } \\
\text { ลี่ }\end{array}$ & 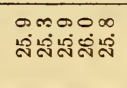 & 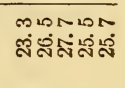 \\
\hline 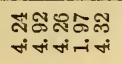 & 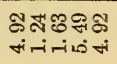 & & $\begin{array}{l}88.85 \\
805\end{array}$ & Pृ & m & 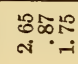 & 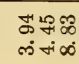 & $\begin{array}{l}B 8 \mathrm{~m} \\
x^{\circ}+\mathrm{H}^{\circ}\end{array}$ & 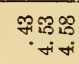 & ד) & 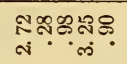 & 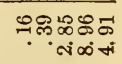 \\
\hline
\end{tabular}

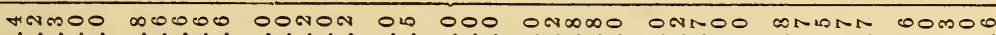

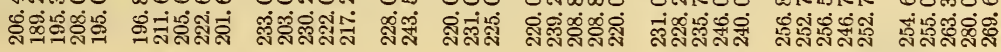

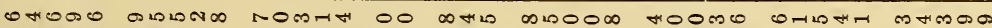

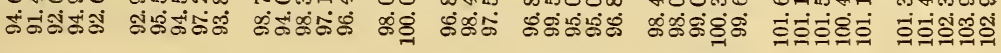

000000000000000000000000000000000000000

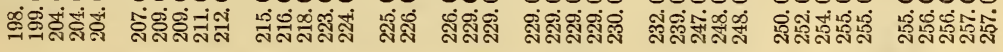

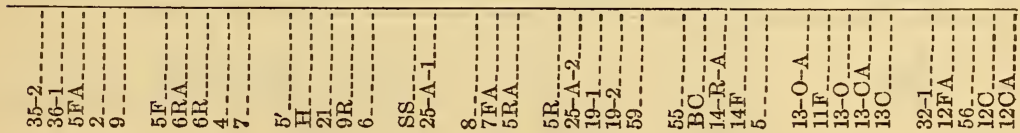




\begin{tabular}{|c|c|c|c|c|c|c|c|}
\hline 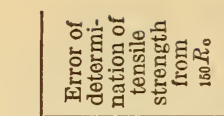 & 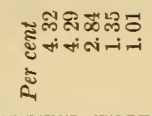 & 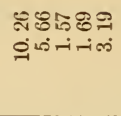 & 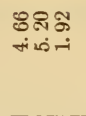 & $\begin{array}{l}5+8 \\
\text { a }\end{array}$ & 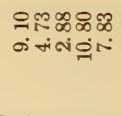 & 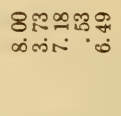 & 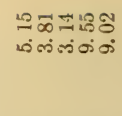 \\
\hline 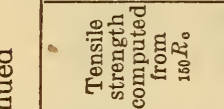 & 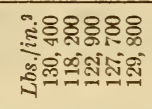 & 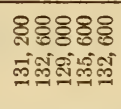 & 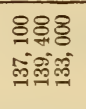 & 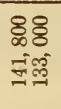 & 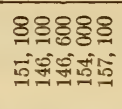 & 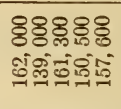 & 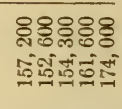 \\
\hline 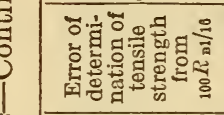 & 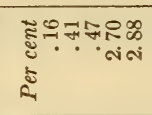 & 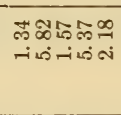 & 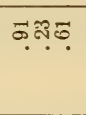 & $\begin{array}{l}\infty \\
\substack{\infty \\
\text { tit. } \\
\text { tit }}\end{array}$ & 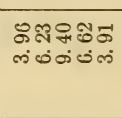 & 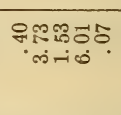 & 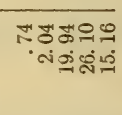 \\
\hline 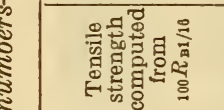 & 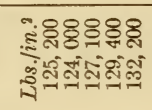 & 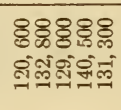 & 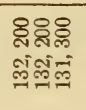 & 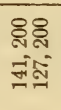 & 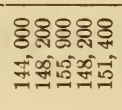 & 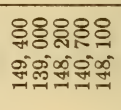 & 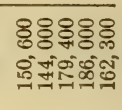 \\
\hline 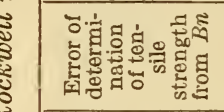 & 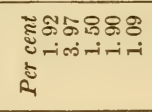 & 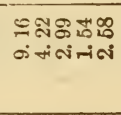 & 禺昂: & 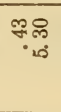 & 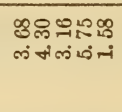 & 유유\& & 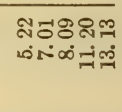 \\
\hline 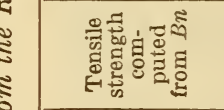 & 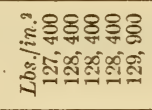 & 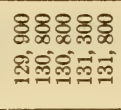 & 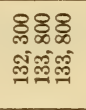 & 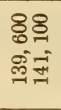 & 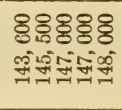 & 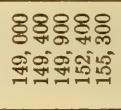 & 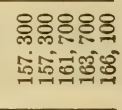 \\
\hline 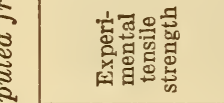 & 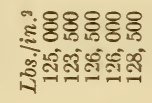 & 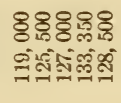 & 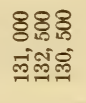 & 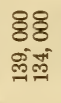 & 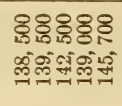 & 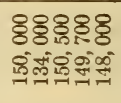 & 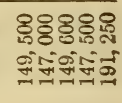 \\
\hline 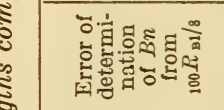 & 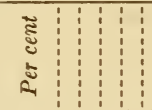 & : & & & & & is \\
\hline 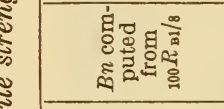 & & $\begin{array}{l}0 \\
0 \\
\vdots \\
\vdots\end{array}$ & & & & & \\
\hline 兘 & & 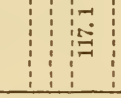 & & & & & \\
\hline 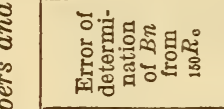 & 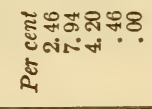 & 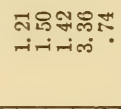 & 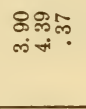 & 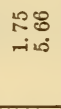 & 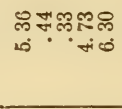 & 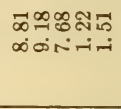 & 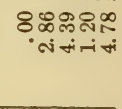 \\
\hline 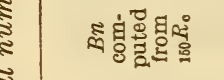 & 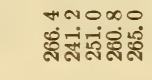 & 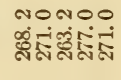 & 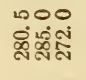 & 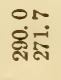 & 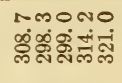 & 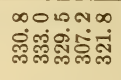 & 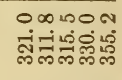 \\
\hline : & 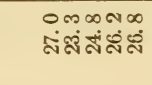 & 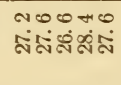 & $\begin{array}{l}\infty+1 \\
\text { ลูละ่ }\end{array}$ & 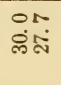 & 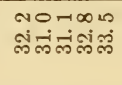 & 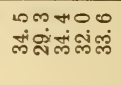 & 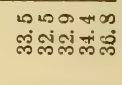 \\
\hline 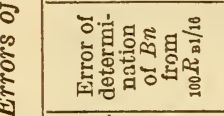 & 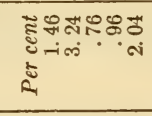 & 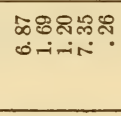 & $\exists 85$ & 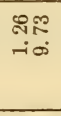 & 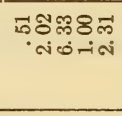 & 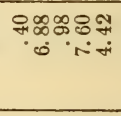 & 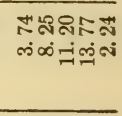 \\
\hline 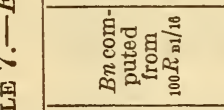 & 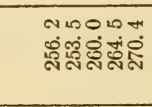 & 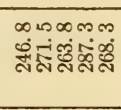 & 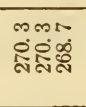 & 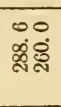 & 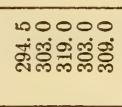 & 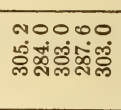 & 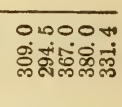 \\
\hline 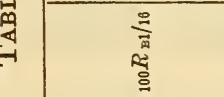 & 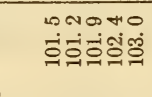 & 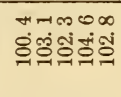 & 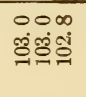 & No & 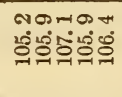 & 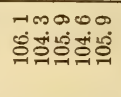 & 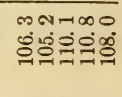 \\
\hline 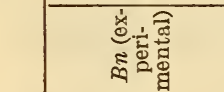 & 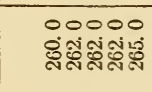 & 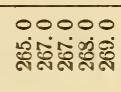 & 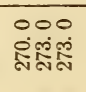 & 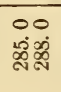 & 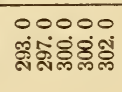 & 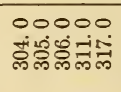 & 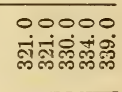 \\
\hline 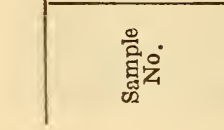 & & 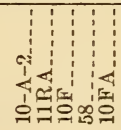 & 选 & 年 & 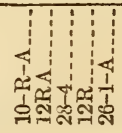 & 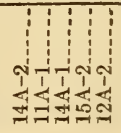 & 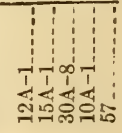 \\
\hline
\end{tabular}




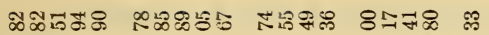

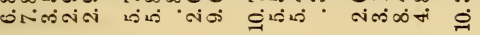

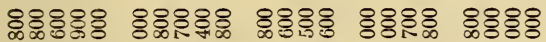

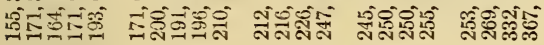

유요요 \%유유

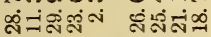

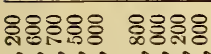

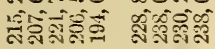

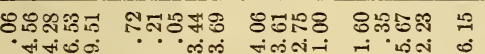

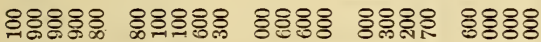

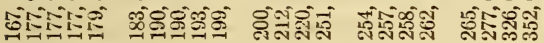

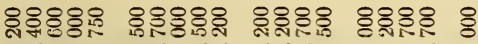

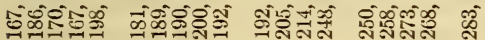

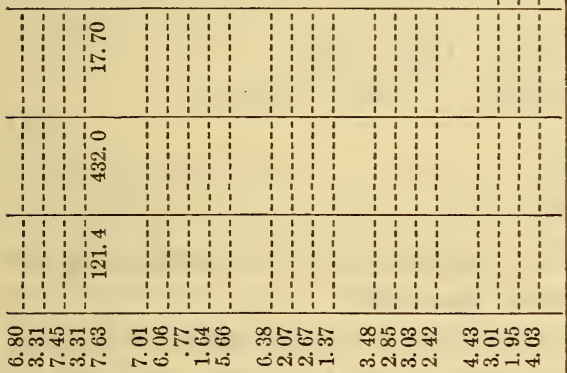

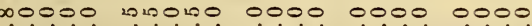

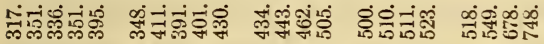

NHOHO NNDLO HOOL OONA NIDHO

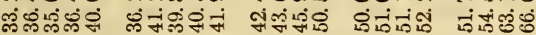

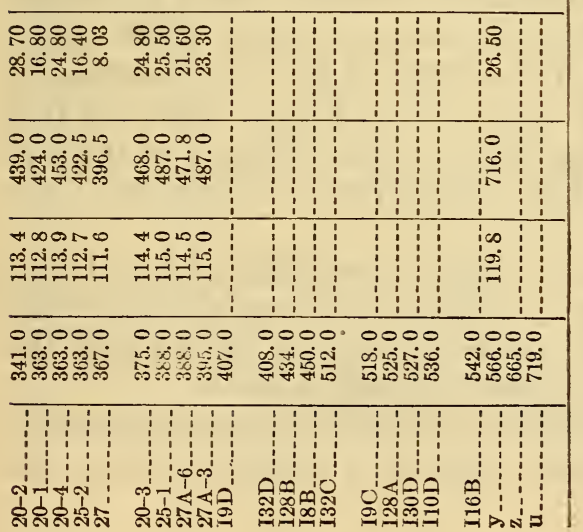


TABLE 8.-Average errors of Bn's computed from Rockwell numbers

\begin{tabular}{|c|c|c|c|c|c|}
\hline$B n$ 's computed & $\begin{array}{l}\text { Experimen- } \\
\text { tal } B n\end{array}$ & $\begin{array}{l}\text { Experimen- } \\
\text { tal Rockwell } \\
\text { numbers }\end{array}$ & $\begin{array}{l}\text { Number of } \\
\text { observa- } \\
\text { tions }\end{array}$ & $\begin{array}{c}\text { Average } \\
\text { error of } \\
\text { computed } \\
B n\end{array}$ & $\begin{array}{l}\text { A verage } \\
\text { error of } \\
\text { computed } \\
B n \text { for the } \\
\text { range of } \\
\text { practical } \\
\text { application }\end{array}$ \\
\hline From ${ }_{100} R_{51 / 16 \ldots}$ & $\begin{array}{r}28 \text { to } 75 \\
75 \text { to } 150 \\
150 \text { to } 225 \\
225 \text { to } 300 \\
\text { Orer } 300\end{array}$ & $\begin{array}{r}-40 \text { to }+35 \\
35 \text { to } 82 \\
82 \text { to } 97 \\
97 \text { to } 100 \\
\text { Over } 106\end{array}$ & $\begin{array}{r}9 \\
14 \\
51 \\
43\end{array}$ & $\begin{aligned} & 5.62 \\
& 2.24 \\
& 3.04 \\
& 3.06 \\
& \text { (1) }\end{aligned}$ & 2. 94 \\
\hline From ${ }_{150} R_{\mathrm{c}-\ldots}$ & $\begin{array}{r}68 \text { to } 100 \\
100 \text { to } 200 \\
200 \text { to } 300 \\
300 \text { to } 400 \\
\text { Over } 400\end{array}$ & $\begin{array}{r}-35 \text { to }-20 \\
-20 \text { to }+16 \\
16 \text { to } 31 \\
31 \text { to } 40 \\
\text { Over } 40\end{array}$ & $\begin{array}{r}4 \\
11 \\
47 \\
33\end{array}$ & $\begin{array}{l}9.22 \\
4.38 \\
2.69 \\
4.10\end{array}$ & 3.40 \\
\hline From ${ }_{100} R_{\mathrm{B} 1 / 8 \ldots}$ & $\begin{array}{r}28 \text { to } 100 \\
100 \text { to } 225 \\
225 \text { to } 350 \\
\text { Orer } 350\end{array}$ & $\begin{array}{r}0 \text { to } 90 \\
90 \text { to } 114 \\
114 \text { to } 120 \\
\text { Over } 120\end{array}$ & $\begin{array}{r}13 \\
17 \\
7\end{array}$ & $\begin{array}{r}6.82 \\
6.40 \\
7.08 \\
(1)\end{array}$ & 6.68 \\
\hline
\end{tabular}

1 Error increases as hardness increases.

As the basis for this correction the results obtained on hard steels (see Table 7, samples I9D to $u$ ) were used. With this correction the formula for $B n$ is

or

$$
B n=\frac{1,420,000}{\left(100-{ }_{150} R_{\mathrm{c}}\right)^{2}} \times \frac{100-{ }_{150} R_{\mathrm{c}}}{57}
$$

$$
B n=\frac{25,000}{100-{ }_{150} R_{\mathrm{c}}}
$$

It should be remembered that this formula is to be used only for materials the ${ }_{150} R_{\mathrm{c}}$ of which is greater than 40 .

The nature of the discrepancy mentioned above may be caused by the elastic recovery of indented material on the one hand and by the presence of a rounded apex of the cone on the other hand. It is evident that if there were no elastic recovery of indented material the difference between the Rockwell number and the dial reading while the specimen is under major load should be equal to the deformation of the frame of the Rockwell machine due to the major load. If the reading of the dial, while the specimen is under major load, is $a$, and the deformation of the frame is $b$, then theoretically the Rockwell number is equal to $a+b$. This follows from the fact that while the major load is being removed the reading $a$ of the dial is increased by the amount $b$, which constitutes the recovery of the frame.

But the separate determinations of $b$ had shown that $a+b$ is always less than the Rockwell number. This can be explained by the elastic recovery of the indented material, because the smaller the depth of indentation, the higher is the Rockwell number.

The Brinell number calculated from $a+b$ would be much nearer to the experimental value of $B n$ than when it is calculated from the actual Rockwell number. 
The corrected formula for $B n$,

$$
B n=\frac{25,000}{100-{ }_{150} R_{\mathrm{c}}}
$$

is of the same type as the formula

$$
B n=\frac{C}{130-R_{\mathrm{B}}}
$$

which indicates that for rery hard materials the depth of indentation made by the cone follows the same law as for the ball. As a matter of fact the apex of the cone is rounded and it is evident that on very hard material for which the depth of indentation is small, the formula can not follow the law which is applicable to the cone.

On harder materials the surface of indentation is more of a sphere while on softer materials the greater part of it is the surface of the cone.

(c) $B n$ computed from ${ }_{100} R_{\mathrm{B} 1 / 8}$ : In this case we have about the same errors for all tested materials up to 350 Brinell beyond which the errors begin to increase rapidly. This indicated that the region of higher error (for soft materials) lies probably below 28 Brinell.

\section{RESULTS OF EARLIER INVESTIGATORS}

The desirability of having some means for comparison of the Rockwell and the Brinell numbers was recognized with the increased use of the Rockwell machine. During the last few years several investigations were made for the purpose of obtaining the experimental relationships between the Rockwell and the Brinell numbers. The summary of these investigations and the principal results obtained are found below:

(1) S. C. Spalding, Transactions of the American Society for Steel Treating, October, 1924.

The experiments were made on tungsten steels, with the tungsten content of about 17 per cent, which were drawn at different temperatures. The results showed that within the range of 300 and 650 the Brinell number is approximately proportional to the Rockwell cone number. No conversion formula was recommended, but the relationship between the Rockwell cone number and the Brinell number may be roughly expressed by the equation: $B n=12.5 R_{\mathrm{c}}-137$.

(2) I. H. Cowdrey, Transactions of the American Society for Steel Treating, February, 1925.

A great variety of ferrous and nonferrous materials were tested, which included overstrained, cold worked, and heat-treated material. The following equations were derived: 
and

$$
B n=\frac{100 R_{\mathrm{B} 1 / 16}+273}{6.49-0.048_{100} R_{\mathrm{B} 1716}}
$$

$$
B n=\left(\frac{{ }_{50} R_{\mathrm{c}}+192}{88.3}\right)^{6.21}
$$

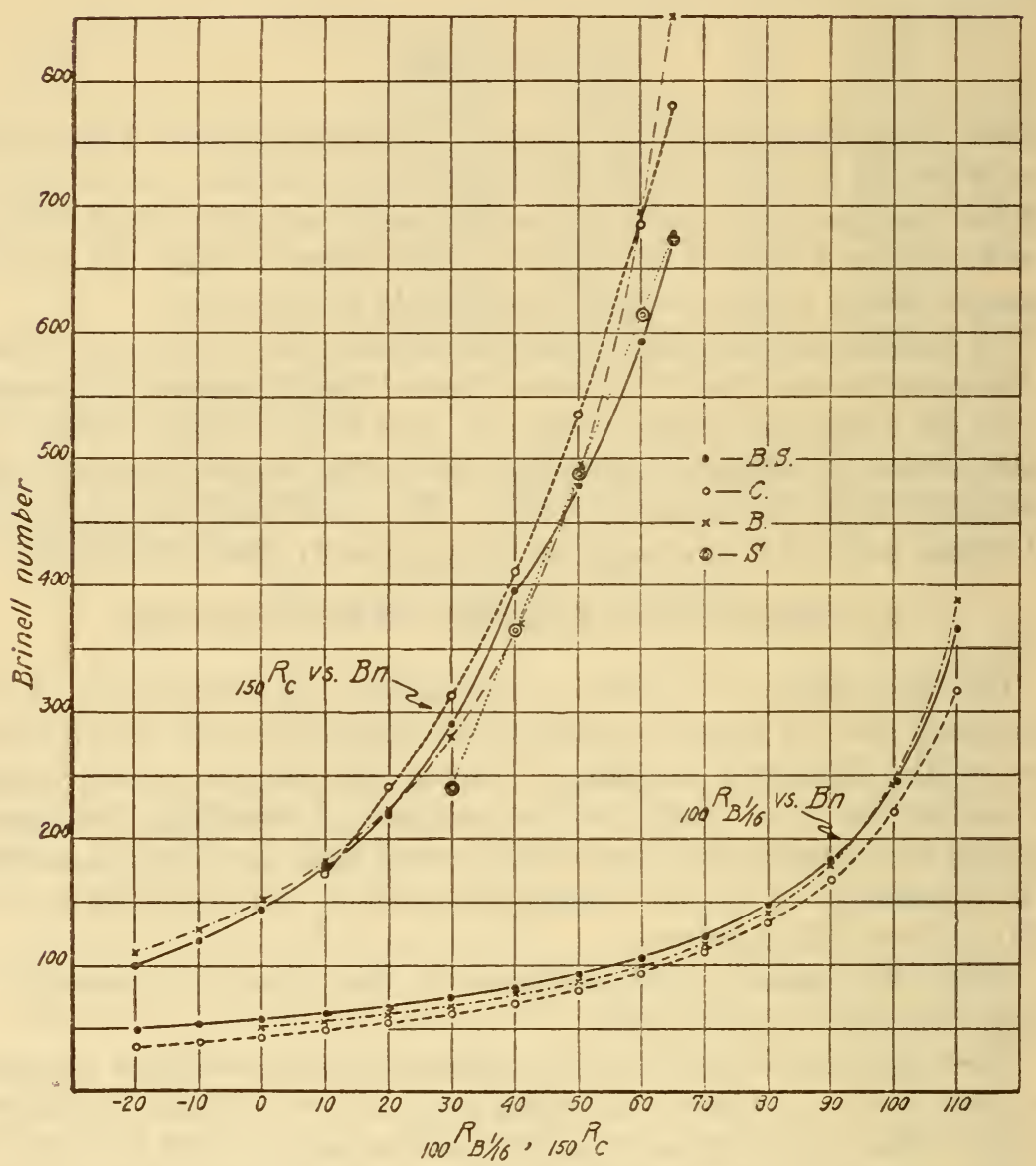

FIg. 6.-Relations between the Rockwell and the Brinell numbers which were obtained by previous investigators

$B S=$ Values obtained in this investigation.

$C=\mathrm{I}$. H. Cowdrey, Trans. A. S. S. T., February, 1925.

$B=$ R. C. Brumfield, Trans. A. S. S. T., June, 1926.

$S=$ S. C. Spalding, Trans. A. S. S. T., October, 1924.

(3) R. C. Brumfield, Transactions of the American Society for Steel Treating, June, 1926.

These tests also included nonferrous materials and differently treated steels, The following equations were derived: 
and

$$
B n=\frac{6,600}{127-{ }_{100} R_{\mathrm{B} 1{ }_{16}}}
$$

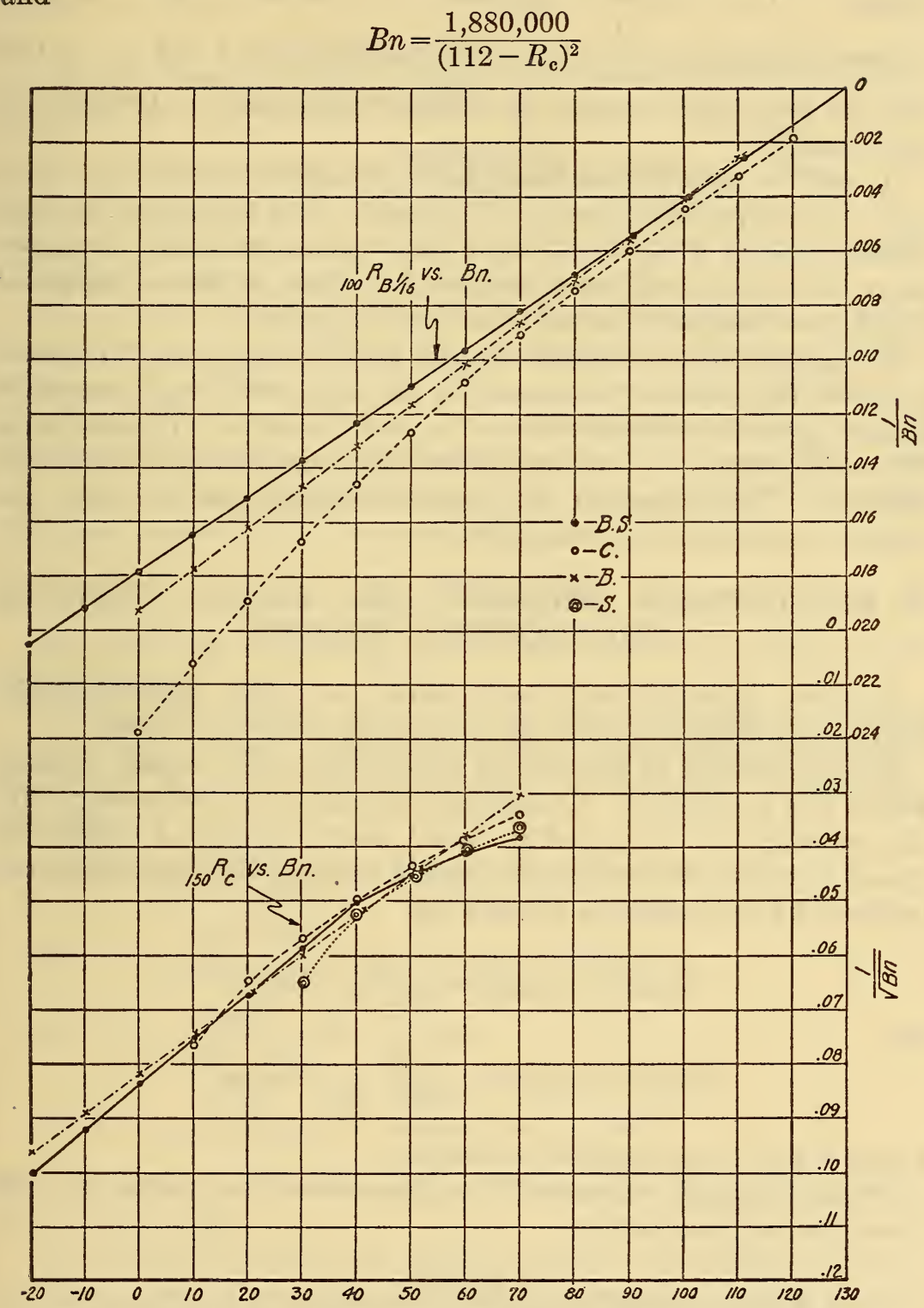

FIG. 7.-Relations between the Rockwell and the Brinell numbers which were obtained by previous investigators

$B S=$ Values obtained in this investigation.

$C=$ I. H. Cowdrey, Trans. A. S. S. T., February, 1925

$B=$ R. C. Brumfield, Trans. A. S. S. T., June, 1926.

$S=$ S. C. Spalding, Trans. A. S. S. T., October, 1924.

The results obtained in these investigations are plotted in Figures 6 and 7. In Figure 6 the Brinell and the Rockwell numbers are 
plotted on a uniform scale, so that a ready comparison of the Brinell numbers computed from the Rockwell numbers can be made. In Figure 7 the Rockwell numbers are plotted: ${ }_{100} R_{\mathrm{B} 1 / 16}$ against $\frac{1}{B n}$ and ${ }_{150} R_{\mathrm{c}}$ against $\frac{1}{\sqrt{B n}}$ as it was done in Figures 3 and 4 . In this way the differences between the different equations are brought out more clearly.

It will be noted that Brumfield's equations are of the same type as the equations given in this paper. The agreement between the two groups of the equations is fairly good, except for the upper range of the Rockwell cone number, for which, as it was explained in (IX), a corrected equation is used in this paper.

No attempt has been made in this work to determine the extent to which the values of constants in the Rockwell-Brinell equations depend upon the characteristics of a given machine. It is probable that the constants in these equations may vary slightly for different machines. This, however, is a question which can be made the subject of a separate investigation.

\section{RELATIONSHIP BETWEEN THE TENSILE STRENGTH AND ROCKWELL NUMBER}

Previous investigators ${ }^{8}$ have found a rough proportionality between the Brinell number and the tensile strength of steels.

Tensile strength in pounds per square inch $=K \times$ Brinell number where $K$ is a constant. Combining this empirical relationship with the semiempirical relationships found above we should expect the tensile strength of a steel to be roughly determinable from Rockwell numbers by the equations of the form:

and

$$
\text { Tensile strength }=\frac{A}{130-R_{\mathrm{B}}} \mathrm{lbs} . / \text { in. }^{2}
$$

$$
\text { Tensile strength }=\frac{\mathrm{B}}{\left(100-R_{\mathrm{c}}\right)^{2}} \mathrm{lbs} \cdot / \mathrm{in} .^{2}
$$

where $A$ and $B$ are empirical constants.

These empirical constants were determined for steels. It was found that approximately, and

(a) Tensile strength $=\frac{3,750,000}{130-{ }_{100} R_{\mathrm{B} 1 / 16}} \mathrm{lbs} . /$ in. $^{2}$ for ${ }_{100} R_{\mathrm{B} 1 / 16}<90$

Tensile strength $=\frac{3,570,000}{130-{ }_{100} R_{\mathrm{B} 1 / 16}} \mathrm{lbs} . /$ in..$^{2}$ for ${ }_{100} R_{\mathrm{B} 1 / 16}$ from 90 to 100

${ }^{8} \mathrm{~A}$ complete list of references to them and the account of the results obtained will be found in "Die Brinellsche Kugeldruckprobe" by P. W. Döhmer, pp. 42-70, Berlin; 1925. 
and

(b) Tensile strength $=\frac{730,000,000}{\left(100-{ }_{150} R_{\mathrm{c}}\right)^{2}}$ lbs./in. ${ }^{2}$ for ${ }_{150} R_{\mathrm{c}}<10$

Tensile strength $=\frac{695,000,000}{\left(100-{ }_{150} R_{\mathrm{c}}\right)^{2}} \mathrm{lbs}$./in. ${ }^{2}$ for ${ }_{150} R_{\mathrm{c}}$ from 10 to 40 and

$$
\text { Tensile strength }=\frac{12,250,000}{100-{ }_{150} R_{\mathrm{c}}} \mathrm{lbs} . / \text { in. }^{2} \text { for }{ }_{150} R_{\mathrm{c}}>40
$$

No discernible relationships were found between the tensile strengths and the Rockwell numbers of nonferrous metals.

The values of average errors, of the determination of tensile strength from a Rockwell or Brinell number, are given in Table 7 . These average errors are all of about the same magnitude. In comparatively few cases these errors were greater than 10 per cent. This can be partly explained by the fact that the indentations were not made in the immediate vicinity of that section of the tensile specimen where the fracture occurred.

\section{SUMMARY}

The following conclusions were drawn from the results of this investigation:

(1) For all the metals tested (see the list of materials) the Brinell number may within an error of plus or minus 10 per cent be estimated from the Rockwell numbers, using the following semiempirical formulas:
(a) $B n=\frac{7,300}{130-{ }_{100} R_{\mathrm{B} 1 / 16}}$ for ${ }_{100} R_{\mathrm{B} 1 / 16}$ from 35 to 100 .
(b) $B n=\frac{1,420,000}{\left(100-{ }_{150} R_{\mathrm{c}}\right)^{2}}$ for ${ }_{150} R_{\mathrm{c}}$ from -20 to 40
(c) $B n=\frac{25,000}{100-{ }_{150} R_{\mathrm{c}}}$ for ${ }_{150} R_{\mathrm{c}}>40$
(d) $B n=\frac{3,710}{130-{ }_{100} R_{\mathrm{B} 118}}$ for ${ }_{100} R_{\mathrm{B} \frac{1}{8}}$ from 0 to 120

The average errors of the values obtained from the formulas was about 5 per cent.

(2) For ferrous metals the tensile strength may within an error of plus or minus 15 per cent be estimated from the Rockwell numbers using the following empirical equations: and

(a) Tensile strength $=\frac{3,750,000}{130-{ }_{100} R_{\mathrm{B} 1 / 16}} \mathrm{lbs} . /$ in. $^{2}$ for ${ }_{100} R_{\mathrm{B} 1 ! 16}<90$

Tensile strength $=\frac{3,570,000}{130-{ }_{100} R_{\mathrm{B} 1 / 16}} \mathrm{lbs} . /$ in. $^{2}$ for ${ }_{100} R_{\mathrm{B} 1 / 16}$ from 90 to 100 . 
(b) Tensile strength $=\frac{730,000,000}{\left(100-{ }_{150} R_{\mathrm{c}}\right)^{2}} \mathrm{lbs}$./in. ${ }^{2}$ for ${ }_{150} R_{\mathrm{c}}<10$ and and

$$
\text { Tensile strength }=\frac{695,000,000}{\left(100-{ }_{150} R_{\mathrm{c}}\right)^{2}} \mathrm{lbs} \cdot / \text { in. }^{2} \text { for }{ }_{150} R_{\mathrm{c}} \text { from } 10 \text { to } 40
$$

$$
\text { Tensile strength }=\frac{12,250,000}{100-{ }_{150} R_{\mathrm{c}}} \mathrm{lbs} . / \text { in. } .^{2} \text { for }{ }_{150} R_{\mathrm{c}}>40 .
$$

The average errors of the values obtained by these formulas was less than 10 per cent.

(3) For nonferrous metals no discernible relationship were found between any of the indentation numbers and the tensile strength.

(4) No comprehensive series of similar materials with various heat or mechanical treatment were tested so that no conclusion can be drawn as to the extent to which these errors might be reduced in such a series by choosing proper coefficients for conversion formulas for each series separately. These coefficients might, if desirable, be determined for a given material by inserting into the theoretical formula (1) the experimental values of the quantities which are being compared, for instance, Rockwell number and Brinell number, or Rockwell number and tensile strength, and solving the formula for the coefficient.

Washington, August 5, 1926. 